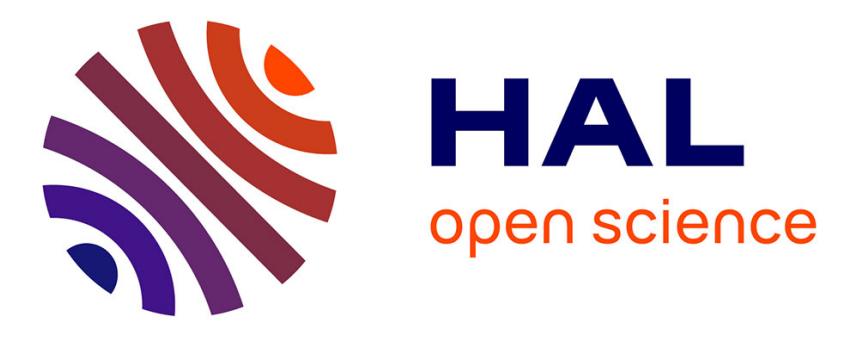

\title{
Divanillin-Based Epoxy Precursors as DGEBA Substitutes for Biobased Epoxy Thermosets
}

Etienne Savonnet, Etienne Grau, Stéphane Grelier, Brigitte Defoort, Henri

Cramail

\section{- To cite this version:}

Etienne Savonnet, Etienne Grau, Stéphane Grelier, Brigitte Defoort, Henri Cramail. Divanillin-Based Epoxy Precursors as DGEBA Substitutes for Biobased Epoxy Thermosets. ACS Sustainable Chemistry \& Engineering, 2018, 6 (8), pp.11008-11017. 10.1021/acssuschemeng.8b02419 . hal-01917945

\section{HAL Id: hal-01917945 \\ https://hal.science/hal-01917945}

Submitted on 20 Nov 2019

HAL is a multi-disciplinary open access archive for the deposit and dissemination of scientific research documents, whether they are published or not. The documents may come from teaching and research institutions in France or abroad, or from public or private research centers.
L'archive ouverte pluridisciplinaire HAL, est destinée au dépôt et à la diffusion de documents scientifiques de niveau recherche, publiés ou non, émanant des établissements d'enseignement et de recherche français ou étrangers, des laboratoires publics ou privés. 


\title{
Divanillin-based epoxy precursors as DGEBA substitutes for bio-based epoxy thermosets
}

Received 00th January 2018, Accepted 00th January 20xx DOI: $10.1039 / x 0 x x 00000 x$

www.rsc.org/

\author{
Etienne Savonnet ${ }^{a, b, c}$, Etienne Grau ${ }^{a, b}$, Cédric Le Coz $^{b}$, Stéphane Grelier*a,b ${ }^{* a i g i t t e ~}$ \\ Defoort $^{c}$ and Henri Cramail*a,b
}

\begin{abstract}
Bio-based epoxy monomers from divanillyl alcohol were successfully synthesized and fully characterized. Diglycidylether of divanillyl alcohol (DiGEDVA), triglycidylether of divanillyl alcohol (TriGEDVA) and tetraglycidyl of divanillyl alcohol (TetraGEDVA) were cured with cyclo-aliphatic diamine (IPDA) a common diamine hardener. Main properties of these vanillin-based epoxy resins were determined by DSC, TGA, DMA, tensile tests and compared to DGEBA-based reference. These bio-based systems displayed phase transition T $\alpha$ from 140 to $200{ }^{\circ} \mathrm{C}$ and exhibited thermal degradation comparable to the DGEBA-based network with high char residue. Such bio-based aromatic monomers are promising substitutes to the DGEBA and can be used in high performance epoxy resin applications as bio-based aromatic polyglycidylethers.
\end{abstract}

\section{Introduction}

Structural adhesives are an important class of materials in aerospace industry, notably. They advantageously replace mechanical joining because of their excellent mechanical performances, good thermal properties and weight saving. ${ }^{1}$ Among them, epoxy adhesives represent an important family and are mostly derived from bisphenol-A (BPA), ${ }^{2}$ a reprotoxic substance, subjected to strong regulation. ${ }^{3-8}$ Developing substitutes to BPA is thus a real challenge to tackle. In addition to health care issues, the need for renewable building-blocks becomes today crucial. ${ }^{9}$ Subsequently, the design of effective bio-based substitutes to diglycidylether of bisphenol-A (DGEBA) is a challenge both for environmental and healthcare concerns.

Vegetable oils are one of the most important classes of renewable sources due to their abundant availability and rather low price. ${ }^{10,11}$ However, their aliphatic structures do not generally allow the achievement of high performance epoxy materials. ${ }^{12,13}$ The design of bio-based epoxy thermosets from synthons exhibiting a more rigid skeleton, such as rosin, glucose derivatives or cardanol was recently reported. ${ }^{14-18}$ Despite the good potential of these bio-sourced materials, their thermal and thermo-mechanical properties are generally lower than the ones of classical DGEBA-based epoxy network. The search for bio-based aromatic and rigid synthons is thus a hot topic in this field. Indeed, aromatic bio-based synthons from tannins and lignin are promising candidates as BPAsubstitutes for the design of epoxy thermosets. ${ }^{19-22}$ However, these renewable resources suffer from their variable and complex structures together with their difficulty to process. In this way, the development for well-defined bio-based aromatic synthons, available in large quantities and easily processable is of prime importance.

In this way, vanillin is a very interesting candidate because

a. Univ. Bordeaux, Laboratoire de Chimie des Polymères Organiques, UMR 5629, 33607 Pessac Cedex, France. E-mail: cramail@enscbp.fr

b. Centre National de la Recherche Scientifique, Laboratoire de Chimie des Polymères Organiques, UMR 5629, 33607 Pessac Cedex, France.

c. ArianeGroup, Rue du général Niox, St-Médard-en-Jalles, 33160, France.

Electronic Supplementary Information (ESI) available: ${ }^{1} \mathrm{H} N M R,{ }^{13} \mathrm{C} N M R$, DSC thermograms, DMA and tensile test traces.

See DOI: $10.1039 / x 0 x x 00000 x$ it is one of the non-hazardous aromatic compounds industrially available from biomass. ${ }^{23}$ Since 1962, the Borregaard's biorefinery has developed the lignin-to-vanillin process at an industrial scale. ${ }^{24}$ Today, lignin-derived vanillin represents $15 \%$ of the overall vanillin production. ${ }^{25,26}$ Therefore, vanillin and derivatives have grown a strong interest as bio-based building blocks for renewable polymers and notably epoxy thermosets. ${ }^{27-36}$ Recently, we have developed an efficient $\mathrm{C}-\mathrm{C}$ coupling of phenolic molecules through enzymatic catalysis leading to a large palette of bisphenolic structures, such as divanillin. ${ }^{36-38}$ In comparison to already existing structures, such bio-sourced bisphenols have a huge potential for epoxy thermosets as the two phenol rings are linked through the 5 and 5' positions without any spacer.

Herein, novel divanillin-based epoxy synthons were thus prepared and used as monomer precursors of epoxy thermosets. The curing was performed with isophorone diamine (IPDA), which is liquid at room temperature and exhibits a good reactivity towards epoxy functions. Thermal and thermo-mechanical properties of the resulting bio-based epoxy thermosets were investigated and compared to the DGEBA-based reference.

\section{Results and discussion}

Synthesis of divanillin-based epoxy monomers

The synthesis of divanillin by selective enzymatic oxidative coupling, followed by the reduction of aldehyde moieties to prepare divanillyl alcohol (DVA) with high yield (85\%) and purity was already reported in previous papers (Scheme 1). ${ }^{36,39}$ The direct glycidylation of DVA was then performed as described in Scheme 2. In addition to the two phenol functions, DVA exhibits two benzylic alcohols, which can be also derivatized into epoxy groups thus yielding to pluriglycidylethers (GEDVA) of DVA. Several works describe the synthesis of epoxy compounds from phenolic substrates in the presence of epichlorohydrin, a phase-transfer catalyst (PTC) and a base. ${ }^{40-42}$ Usually, a large excess of epichlorohydrin is used to prevent the formation of oligomers. Moreover, additional solvents are not necessary during the synthesis as 
epichlorohydrin acts as a reactive solvent. The synthetic pathway adapted for DVA takes place in two steps. First, the PTC eases the nucleophilic substitution of epichlorohydrin with phenol by assisting the phenolate ion into the organic phase. The nucleophilic substitution directly leads to the synthesis of epoxy moieties, but a ring-opening mechanism occurs also yielding "open-epoxy" intermediates. The second step thus consists in adding a base at room temperature in order to close the epoxy ring intermediates. At this stage, the base is also needed to catalyze the glycidylation of the benzyl alcohol moieties. Following this synthetic route, different DVA-based epoxy monomers were prepared: diglycidylether of divanillyl alcohol (DiGEDVA), triglycidylether of divanillyl alcohol (TriGEDVA) and tetraglycidylether of divanillyl alcohol (TetraGEDVA) (Scheme 2). These latter compounds are generally obtained as a mixture at different ratios, which is fractionated by flash chromatography. Nevertheless, two key parameters have been identified to control this reaction, i.e. the sodium hydroxide content and the second step reaction duration. In this way, by tuning these two parameters, the reaction is more oriented towards one type of GEDVA. The kinetics of glycidylation reaction was followed by HPLC with respect to the equivalent number of $\mathrm{NaOH}$ per $\mathrm{OH}$ group (benzylic alcohol + phenol) as shown on the Figure 1. For a ratio $\mathrm{NaOH} / \mathrm{OH}$ equal to 10 , TetraGEDVA is mainly obtained with about $90 \%$ yield. In contrast, at lower $\mathrm{NaOH} / \mathrm{OH}$ ratios, DiGEDVA is mainly obtained ( $80 \%$ yield). Subsequently, it is rather convenient to selectively obtain a majority of DiGEDVA or TetraGEDVA with very good yields. GEDVA monomers were then fully characterized by HRMS and NMR spectroscopy (Figure $\mathbf{2}$ andFigures SI-S10). The glycidylation of phenols was confirmed by the presence of signals of epoxy moieties at 2.36 , 2.60, 2.95, 3.74 and $3.88 \mathrm{ppm}$.

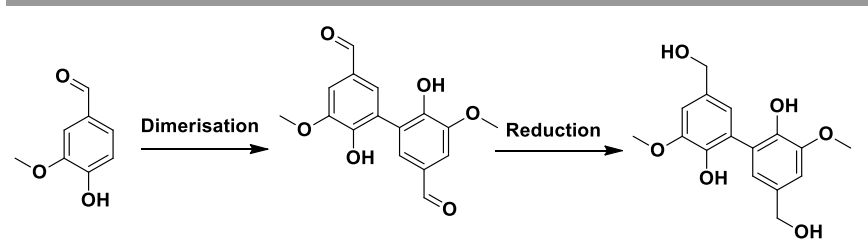

Scheme 1 Synthesis of divanillyl alcohol from vanillin

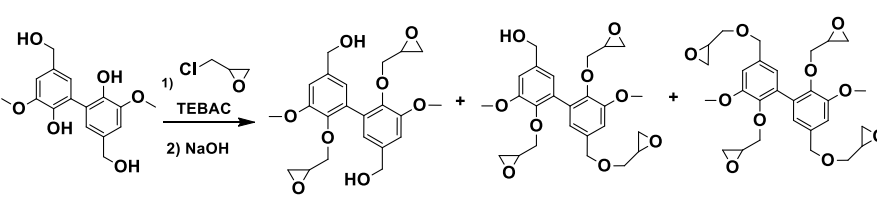

Scheme 2 Structure of bio-based epoxy monomers from DVA, from left to right: diglycidylether of divanillyl alcohol (DiGEDVA), triglycidylether of divanillyl alcohol (TriGEDVA) and tetraglycidylether of divanillyl alcohol (TetraGEDVA)

Glycidylation of benzyl alcohols of TriGEDVA and TetraGEDVA was confirmed by the characteristics signals of epoxy moieties at $2.55,2.73,3.14,3.28$, and $3.70 \mathrm{ppm}$ and by the gradual decrease of the benzyl alcohol signal at $5.16 \mathrm{ppm}$. In addition, TriGEDVA NMR spectrum shows a duplication of aromatic and methylene signals at 6.71 and 4.47 ppm respectively, reflecting a loss in the symmetry of the molecule. GEDVA monomers were also characterized by FTIR (Figure S15). Indeed, benzylic alcohol signal at $3400 \mathrm{~cm}^{-1}$ gradually disappears with the formation of epoxide functions. In the case of TetraGEDVA, this specific band has vanished, while for the DiGEDVA, the band is still visible. The $\mathrm{C}-\mathrm{H}$ and $\mathrm{C}=\mathrm{C}$ aromatic ring stretching are also visible at $2920 \mathrm{~cm}^{-1}$ and $1600 \mathrm{~cm}^{-1}$, respectively.

The processability of epoxy prepolymers is a key parameter in the handling of such substrates at the industrial scale. The thermal and physical properties of GEDVA monomers were thus determined and compared to DGEBA (Table 1). DGEBA monomer is a solid, which can be melted into very low viscosity liquid at a temperature above $45^{\circ} \mathrm{C}$. It can thus be homogeneously mixed with various curing agents. The viscosity of GEDVA monomers is thus very dependent on the number of epoxy groups carried by the substrate. This feature can be explained by the presence of two free benzylic alcohol moieties in DiGEDVA compound, which can undergo hydrogen bonds and thus increase the viscosity. As DiGEDVA exhibits a $\mathrm{Tg}=16^{\circ} \mathrm{C}$ and a viscosity of $1300 \mathrm{~Pa} . \mathrm{s}$ at $40^{\circ} \mathrm{C}$, it is thus a highly viscous material at RT that is difficult to blend with any hardener.
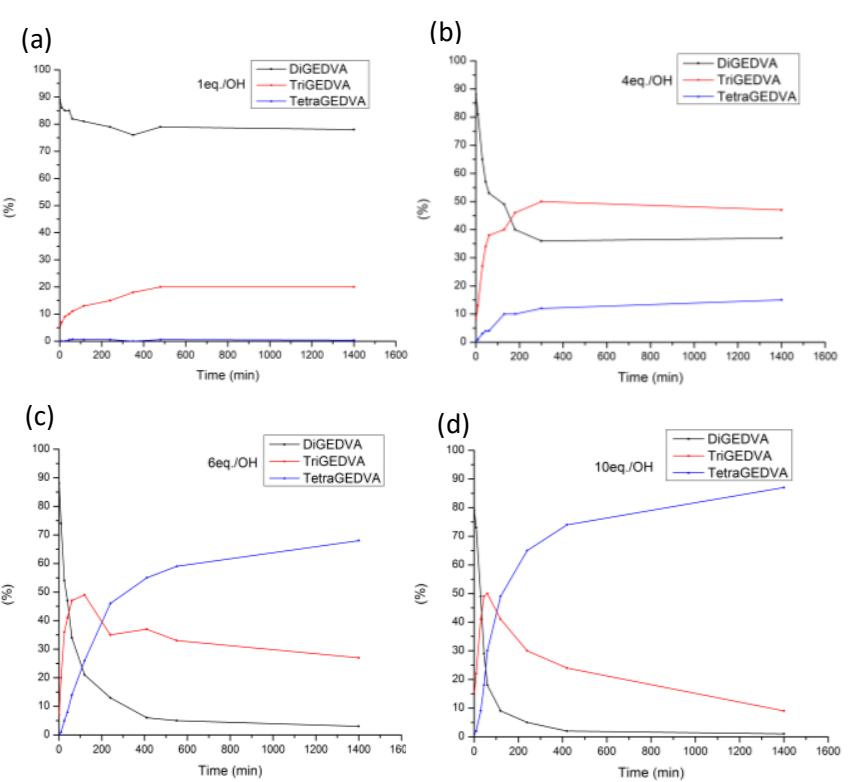

Figure 1 Variation with time of DiGEDVA, TrigEDVA and TetraGEDVA with respect to $\mathrm{NaOH}$ eq./OH; $1 \mathrm{NaOH}$ eq./OH (a), $4 \mathrm{NaOH}$ eq./OH (b), $6 \mathrm{NaOH}$ eq./OH (c), $10 \mathrm{NaOH}$ eq./OH (d)

Table 1 Thermal and physical properties of DGEBA and GEDVA monomers

\begin{tabular}{lcccc}
\hline \multicolumn{1}{c}{ Properties } & DGEBA & DigEDVA & TrigEDVA & TetraGDVA \\
\hline Melting point $\left({ }^{\circ} \mathrm{C}\right)$ & 45 & - & - & - \\
Glass transition $\left({ }^{\circ} \mathrm{C}\right)$ & -18 & 16 & -6 & -15 \\
Viscosity $(\mathrm{Pa} . \mathrm{s})^{\mathrm{a}}$ & 1 & 1300 & 60 & 2 \\
EEW th. & 170 & 209 & 158 & 132 \\
EEW exp. & 171 & 232 & 164 & 129 \\
\hline aat $40^{\circ} \mathrm{C}$ & & & &
\end{tabular}

In contrast, TetraGEDVA is much easier to handle as it exhibits a $\mathrm{Tg}=-15^{\circ} \mathrm{C}$ and a viscosity of $2 \mathrm{~Pa}$.s at $40^{\circ} \mathrm{C}$ and TrigEDVA exhibits thermal and mechanical properties in between those of Di- and TetraGEDVA. In addition to the fact that is possible to recover pure $\mathrm{Di}$, Tri or TetraGEDVA after separation step, the use of mixtures of these polyfunctional structures will 
enable to control the processing of these prepolymers. Moreover, the thermomechanical properties of these different blends cured with IPDA were also investigated and the formulation of mixture of GEDVA monomers proved to be an efficient way to tune the average properties of the epoxy thermosets (see Figure S18 and Figure S19).

According to the standard test method, the EEW (Epoxy Equivalent Weight) of GEDVA monomers was determined and compared with DGEBA reference. ${ }^{43}$ The experimental EEW values, gathered in Table 1, were found slightly higher than theoretical values. This difference in between theoretical and experimental data can be explained by the presence of byproducts or oligomers in the sample. ${ }^{44}$ Indeed, size exclusion chromatography were performed on GEDVA monomers (see Figure S16) and SEC traces revealed the presence of higher molecular mass molecule, especially for the DiGEDVA monomer.

\section{Synthesis and characterizations of epoxy thermosets by DSC}

The reactivity of GEDVA monomers towards the formation of epoxy thermosets was investigated in the presence of isophorone diamine (IPDA), used as curing agent. The control of the stoichiometry ratio, $r$, in between epoxy and $\mathrm{N}-\mathrm{H}$ moieties is a key parameter to obtain an optimal curing, leading to thermosets with controlled properties. This quotient is defined as given in Equation 1:

Equation 1

$$
\boldsymbol{r}=\frac{\boldsymbol{f}_{\text {epoxy }} * \boldsymbol{n}_{\text {epoxy }}}{\boldsymbol{f}_{\text {hardener }} * \boldsymbol{n}_{\text {hardener }}}
$$

Usually the stoichiometric a ratio epoxy/N-H of 1 leads to epoxy thermosets with the highest thermomechanical properties. ${ }^{45}$ This value will be used in the following of the study. The reaction between GEDVA monomers (DiGEDVA, TriGEDVA, TetraGEDVA) and IPDA was performed in DSC capsules and compared with DGEBA system. The polyaddition reaction between an epoxide group and a primary amine occurs in two stages, by successive reaction of each $\mathrm{N}-\mathrm{H}$ linkage with one epoxy equivalent. It has been reported in the literature, $44,46-48$ that primary amines react faster than secondary amines. This feature can be experimentally checked

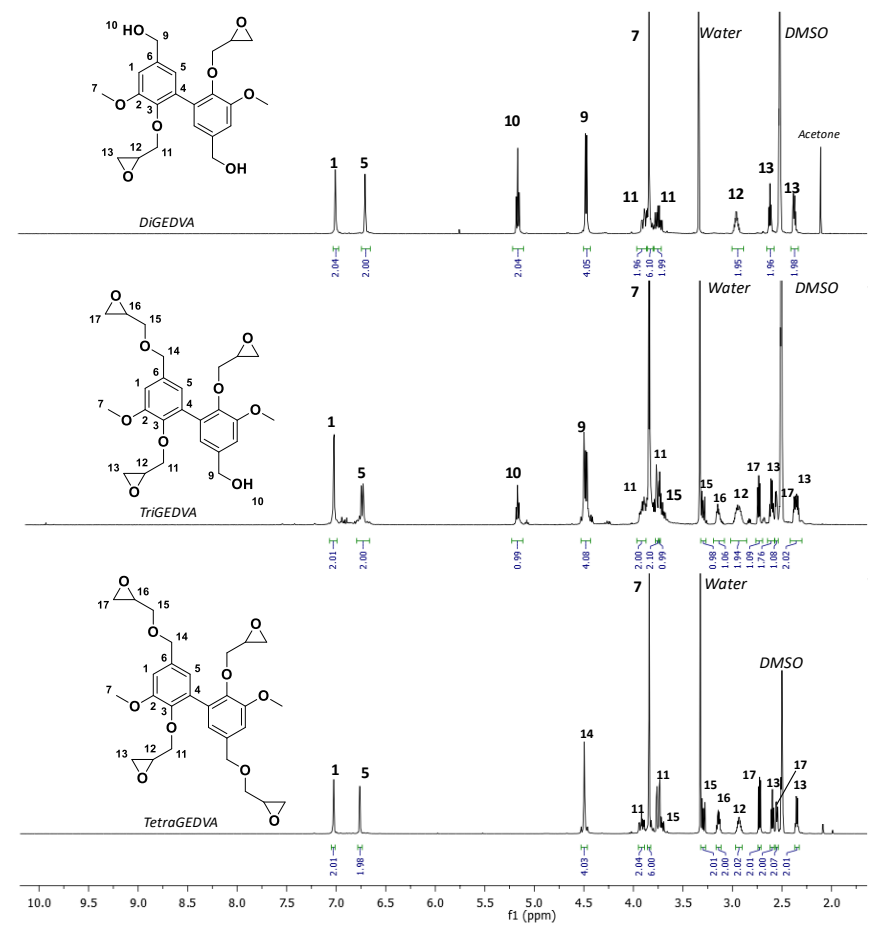

Figure $2{ }^{1} \mathrm{H}$ NMR spectra of DiGEDVA, TrigEDVA and TetraGEDVA in DMSO- $d 6$

by DSC, in the case of tetraGEDVA cured with IPDA, where a first exothermic peak is observed at $100{ }^{\circ} \mathrm{C}$ followed by a second one at $140{ }^{\circ} \mathrm{C}$, which corresponds to the difference of reactivity between primary and secondary amino moieties of IPDA (Figure 3 and Figure S17). It is worth noting that the high viscosity of the DiGEDVA monomer made more difficult the mixing process with IPDA. By consequent, the ratio epoxy/amine may have been distorted by the inhomogeneousity of the mixture.

Different thermodynamical parameters with respect to the curing reactions between GEDVA and IPDA are summarized in Table 2.
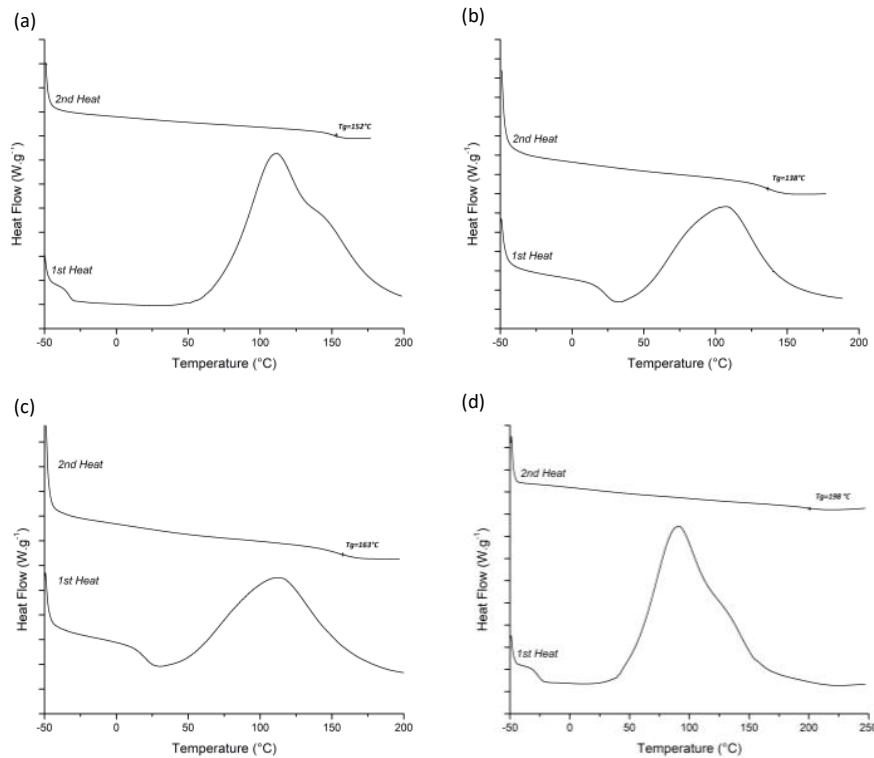

Figure 3 DSC thermograms of (a) DGEBA, (b) DigEDVA, (c) TrigeDVA and (d) TetraGEDVA cured with IPDA for $r=1$ 
Table 2 Thermal properties of epoxy thermosets cured with IPDA

\begin{tabular}{lccc|c|c|}
\hline $\begin{array}{l}\text { Epoxy } \\
\text { prepolymer/IPDA }\end{array}$ & $\begin{array}{c}\text { Tonset } \\
\left({ }^{\circ} \mathbf{C}\right)\end{array}$ & $\begin{array}{c}\mathbf{T}_{\text {Exo. }} \\
\left({ }^{\circ} \mathbf{C}\right)\end{array}$ & $\begin{array}{c}\Delta \mathbf{H} \\
\left(\mathbf{J}^{\left.-g^{-1}\right)}\right.\end{array}$ & $\begin{array}{c}\Delta \mathbf{H} \\
(\mathbf{k J . m o l}\end{array}$ & $\begin{array}{c}\mathbf{T}_{\mathbf{g}} \\
\left({ }^{\circ} \mathbf{C}\right)\end{array}$ \\
\hline DGEBA & 73 & 111 & 430 & 91 & 152 \\
\hline DiGEDVA & 47 & 107 & 180 & 45 & 138 \\
TriGEDVA & 40 & 84 & 324 & 65 & 163 \\
TetraGEDVA & 50 & 92 & 426 & 75 & 198 \\
\hline
\end{tabular}

All the so-formed GEDVA-based thermosets exhibit lower onset temperatures than the DGEBA-based system, demonstrating a high reactivity of these GEDVA monomers towards amino group. In terms of energy released during the curing, TetraGEDVA exhibits an enthalpy of reaction similar to the DGEBA reference. In contrast, DiGEDVA and TrigEDVA exhibit lower total heat reaction. This result could be explained by the fact that reaction with IPDA may have already started during the mixing process. This hypothesis is verified on the Figure $\mathbf{3 b}$ and $\mathbf{3 c}$, where a glass transition temperature higher than the one determined for the monomer is visible during the first heat. This observation confirmed that the curing reaction has already started by forming an early network before to run the DSC analysis.

At the second heating ramp, the so-formed epoxy networks exhibited Tg ranging from 138 to $198^{\circ} \mathrm{C}$ as a function of the GEDVA monomer. TrigEDVA and TetraGEDVA networks displayed higher $\mathrm{Tg}$ than the DGEBA-based system.

\section{Characterization of epoxy thermosets by DMA and mechanical analysis}

In order to evaluate the mechanical properties of these GEDVA-based thermosets, curing reactions were then performed on larger quantities $(2 \mathrm{~g})$ in moulds enabling tensile tests. The thermomechanical features of the epoxy networks were then determined by dynamic mechanical analysis (DMA) using three-point bending geometry. Data are gathered in Table 3. From DMA, the maximum of tan delta called alpha transition $(T \alpha)$ corresponding to the transition from a glassy to a rubbery state could be determined and the cross-linking density $(v)$ could be also estimated from Equation 2, according to rubber-like elasticity theory. ${ }^{49}$

Equation 2

$$
v=\frac{E^{\prime}\left(T_{\alpha+30}\right)}{\phi \cdot R \cdot T_{\alpha+30}}
$$

with $T \alpha$ the maximum of tan delta, $E^{\prime}$ the storage modulus of the network at $T \alpha+30 \mathrm{~K}, \phi$ the front factor approximately equal to 1 in Flory theory ${ }^{50}$ and $\mathrm{R}=8.314 \mathrm{~J} \cdot \mathrm{mol}^{-1} \cdot \mathrm{K}^{-1}$ the gas constant. GEDVA-based epoxy thermosets exhibit $T \alpha$ values ranging from 140 to $200{ }^{\circ} \mathrm{C}$, values mainly influenced by the number of reactive epoxy groups. Indeed, the cross-linking density of TetraGEDVA-based network is almost five times and two times higher than DiGEDVA-based and TriGEDVA-based networks, respectively.
Table 3 Thermomechanical properties of epoxy networks formed after curing with IPDA for $r=1$

\begin{tabular}{lcccc}
\hline $\begin{array}{l}\text { Epoxy } \\
\text { prepolymer/IPDA }\end{array}$ & $\begin{array}{c}\mathbf{T}_{\boldsymbol{\alpha}} \\
\left.\mathbf{(}^{\circ} \mathbf{C}\right)\end{array}$ & $\begin{array}{c}\mathbf{E}^{\prime} \\
(\mathbf{G P a})\end{array}$ & $\begin{array}{c}\mathbf{E}^{\prime}\left(\mathbf{T}_{\boldsymbol{\alpha}+\mathbf{3 0})}\right. \\
(\mathbf{G P a})\end{array}$ & $\begin{array}{c}\mathbf{U} \\
\left(\mathbf{1 0}^{\mathbf{3}} \mathbf{m o l} . \mathbf{m}^{-3}\right)\end{array}$ \\
\cline { 1 - 5 } DGEBA & 155 & 1.7 & 0.035 & 9.2 \\
DiGEDVA & 140 & 1.9 & 0.035 & 9.5 \\
TriGEDVA & 177 & 2.4 & 0.10 & 25 \\
TetraGEDVA & 200 & 2.1 & 0.21 & 49 \\
\hline
\end{tabular}

As expected, segments of highly cross-linked epoxy networks have a reduced mobility thus leading to higher $T \alpha$. In comparison with DGEBA-based thermoset, TetraGEDVA, TriGEDVA showed much higher $\mathrm{Tg}$ and $\mathrm{T} \alpha$ values. The crosslinking density also increase with the functionality of the epoxy used from 9.2 to $4510^{3} \mathrm{~mol} . \mathrm{m}^{3}$. Figure 4 compares the profile of DMA curves obtained for epoxy networks formed after curing of DGEBA and GEDVA with IPDA, respectively. It is worth noting that the intensity of tan delta peak of $\mathrm{Di}$, Tri and TetraGEDVA systems decrease from 1 to 0.2 respectively. This feature could be attributed to the increasing cross-linked density of networks formed upon the curing with IPDA. Indeed, tan delta is the ratio between loss and storage modulus, representing the way in which a material absorbs and disperses energy. In that purpose, a low cross-linked material will have the ability to dissipate more energy by deformation and thus will exhibit a higher tan delta value than a more cross-linked and rigid network. In addition, DGEBA/IPDA and TetraGEDVA/IPDA systems exhibited a broad tan delta, which could also be explained by the heterogeneity of the networks thus formed. 51

Tensile tests were also performed on GEDVA- and DGEBAbased thermosets. Results are summarised in Table $\mathbf{4}$ and tensile traces are available in ESI. DGEBA-based thermoset exhibits a Young's modulus of $1300 \mathrm{MPa}$ and an elongation at break of $6 \%$. In the cases of GEDVA-based thermosets, Young modulus range from 1400 to $1900 \mathrm{MPa}$ and elongation at break from $4 \%$ to $5 \%$. In contrast, DGEBA-based thermoset shows a slightly higher elongation at break. The presence of the spacer between the two phenolic rings allows more flexibility to the networks in comparison with the GEDVAbased thermosets. 

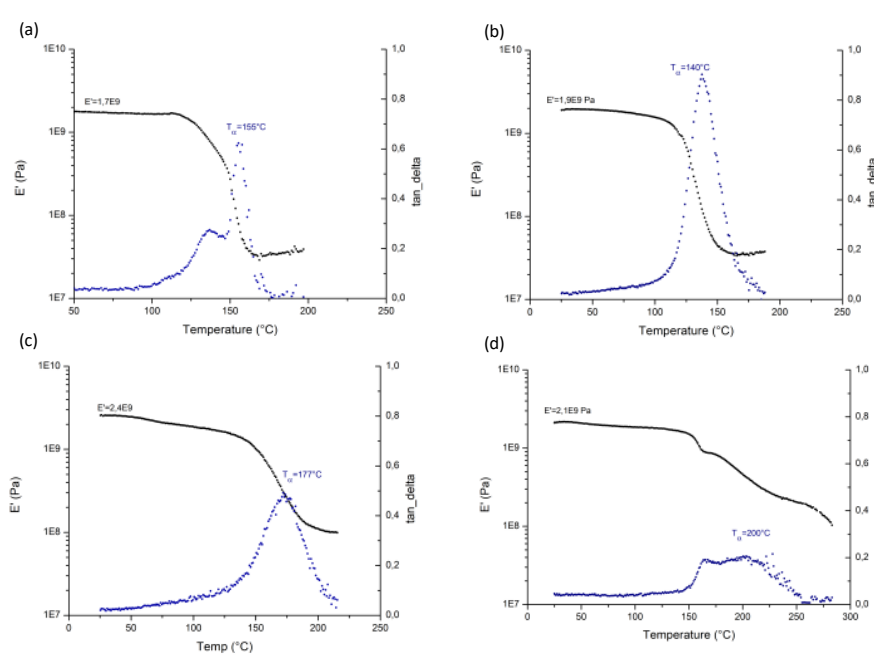

Figure 4 DMA traces of epoxy networks formed after curing with IPDA (a) DGEBA, (b) DigeDVA, (c) TrigEDVA and (d) TetraGEDVA

Table 4 Mechanical properties of epoxy networks formed after curing with IPDA for $r=1$

\begin{tabular}{l|c|c}
\hline & & \\
\hline $\begin{array}{l}\text { Epoxy } \\
\text { prepolymer/IPDA }\end{array}$ & $\begin{array}{c}\text { Young's modulus } \\
\text { (MPa) }\end{array}$ & $\begin{array}{c}\text { Elongation at break } \\
\text { (\%) }\end{array}$ \\
\hline DGEBA & $1350 \pm 100$ & $6,3 \pm 1,1$ \\
DiGEDVA & $1450 \pm 200$ & $3,6 \pm 1$ \\
TriGEDVA & $1550 \pm 150$ & $4,7 \pm 0.5$ \\
TetraGEDVA & $1900 \pm 20$ & $4,5 \pm 1$ \\
\hline
\end{tabular}

\section{Thermal stability of epoxy thermosets}

The thermal degradation behaviors of these networks were investigated by thermogravimetric analysis (TGA). From the two degradation temperatures weight loss $T_{\mathrm{d} 5 \%}$ and $T_{\mathrm{d} 30 \%}$, it is possible to calculate the statistic heat-resistant index $\left(T_{s}\right)$ as follows: 52

Equation 3

$$
T_{S}=0.49 \cdot\left(T_{d 5 \%}+0.6 \cdot\left(T_{d 30 \%}-T_{d 5 \%}\right)\right)
$$

The statistic heat-resistant index $\left(T_{s}\right)$ gives an indication of the thermal stability of an epoxy thermoset. The thermal decomposition behaviours under air of the GEDVA- and DGEBA-based epoxy/IPDA networks are given in Table $\mathbf{5}$ and Figure 5. First, the thermal degradation under air of all the GEDVA-based networks occurs in two stages, a first $40 \%$ weight loss at around $275^{\circ} \mathrm{C}$ and a second $60 \%$ weight loss around at $500{ }^{\circ} \mathrm{C}$. The thermal degradation of DGEBAbased networks starts at around $330{ }^{\circ} \mathrm{C}$ with about $70 \mathrm{wt} \%$ loss followed by a second $30 \mathrm{wt} \%$ loss at $500{ }^{\circ} \mathrm{C}$. The values of statistic heat-resistance index for the GEDVA-based networks are $20^{\circ} \mathrm{C}$ lower than the ones of DGEBA-based network. The faster heat degradation of GEDVA-based system in comparison to DGEBA may be explained by the degradation of methoxy groups linked to the aromatic rings. ${ }^{19,53}$

The thermal degradation of these networks was also investigated under nitrogen (Table 5). The traces showed a single step of degradation process, which starts at around $275^{\circ} \mathrm{C}$ and $350{ }^{\circ} \mathrm{C}$ for GEDVA-based and DGEBA-based networks, respectively. Interestingly, the residual mass at $700{ }^{\circ} \mathrm{C}$ ranges from 24 to $32 \%$ in the case of GEDVA-based networks while DGEBA-based network has a residual mass at $700{ }^{\circ} \mathrm{C}$ of $8 \%$. Some authors reported that the char formation is related to the cross-linking density of the networks. ${ }^{54}$ These values are in agreement with the results obtained with TetraGEDVA and TriGEDVA, which exhibit a high cross-linking density. However, DiGEDVA-based system exhibited the highest char content, whereas its network density is equivalent to

\begin{tabular}{|c|c|c|c|c|c|c|c|c|}
\hline \multirow{2}{*}{$\begin{array}{l}\text { Epoxy } \\
\text { prepolymer } \\
\text { /IPDA } \\
\end{array}$} & \multicolumn{2}{|c|}{$\begin{array}{l}T_{d 5 \%} \\
\left({ }^{\circ} \mathrm{C}\right)\end{array}$} & \multicolumn{2}{|c|}{$\begin{array}{l}T_{d 30 \%} \\
\left({ }^{\circ} \mathrm{C}\right)\end{array}$} & \multicolumn{2}{|c|}{$\mathrm{T}_{\mathrm{s}}$} & \multicolumn{2}{|c|}{$\begin{array}{c}\text { Char }_{600} \\
(\%)\end{array}$} \\
\hline & Air & $N_{2}$ & Air & $\mathrm{N}_{2}$ & Air & $N_{2}$ & Air & $\mathrm{N}_{2}$ \\
\hline DGEBA & 336 & 349 & 364 & 366 & 172 & 176 & 1.1 & 8 \\
\hline DiGEDVA & 273 & 275 & 337 & 334 & 153 & 152 & 0.5 & 32 \\
\hline TriGEDVA & 292 & 296 & 335 & 333 & 156 & 155 & 0.9 & 28 \\
\hline TetraGEDVA & 275 & 276 & 316 & 313 & 147 & 146 & 1.1 & 24 \\
\hline
\end{tabular}
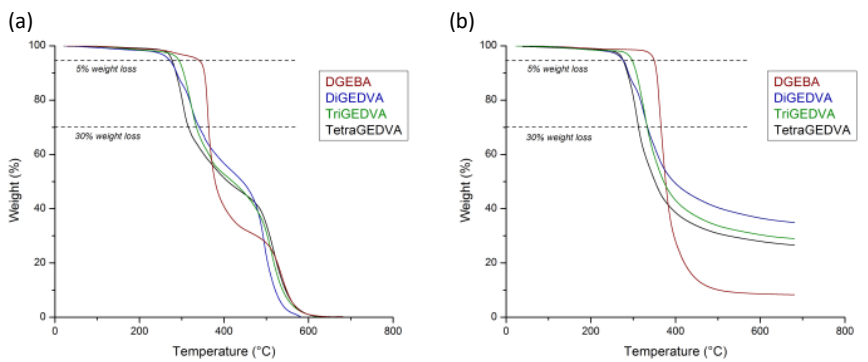

Figure 5 TGA thermograms of epoxy monomers cured with IPDA under (a) Air and (b) N2

DGEBA-based system (Figure 5). The capacity of the free benzyl alcohols on the DiGEDVA structure could react at high temperature, leading to a network density increase and thus higher char yield. High char residue value is a good indication of flame retardancy properties of the materials. ${ }^{55}$ As a consequence, flaming tests have been performed on GEDVAbased samples. In direct contact with flame, DGEBA-based thermoset specimens burn and the combustion spreads rapidly to the rest of the sample. Contrarily, the combustion is rapidly stopped by the direct formation of a char layer at the surface of GEDVA-based thermosets.

\section{Conclusion}

New bio-based epoxy monomers derived from divanillyl alcohol (DVA) were successfully synthesized and characterized. The degree of glycidylation of DVA could be easily tuned leading to GEDVA substrates with two, DiGEDVA, three, TrigEDVA or four, TetraGEDVA, epoxy functions. These GEDVA were then cured with IPDA and this reaction compared with a DGEBA-based reference. The bio-based epoxy thermosets soformed displayed remarkable properties with respect to $\mathrm{Tg}$ and $\mathrm{T} \alpha$ values which range from 140 to $200{ }^{\circ} \mathrm{C}$. In terms of mechanical properties, GEDVA-based systems exhibits similar Young modulus values to the DGEBA-based thermoset, but 
lower elongation at break. Thermal stability of GEDVA-based networks also exhibited similar values to the DGEBA-based reference, but a much higher char residue, which is a promising feature in terms of additional flame retardancy properties. In conclusion, these divanillin-based epoxy substrates were found valuable and realistic alternatives to DGEBA towards high performance epoxy resin applications.

\section{Experimental}

\section{Materials and methods}

Laccase from Trametes versicolor, benzyltriethylammonium chloride (99\%), diglycidylether of bisphenol-A (D.E.R тм 332), tetraethylammonium bromide (98\%), hydrochloric acid (37.5\%) and potassium hydrogen phthalate (99\%) were purchased from Sigma-Aldrich. Epichlorohydrin (99\%) and isophorone diamine (97\%) were purchased from $\mathrm{TCl}$. Vanillin (99\%), perchloric acid solution and sodium borohydride (99\%) were purchased from Acros. Sodium hydroxide was purchased from Fisher. All products and solvents (reagent grade) were used as received, unless mentioned explicitly.

\section{Instrumentations}

All NMR experiments were performed at $298 \mathrm{~K}$ on a Bruker Avance 400 spectrometer operating at $400 \mathrm{MHz}$, in deuterated solvent (DMSO).

Flash chromatography was performed on a Grace Reveleris apparatus, employing silica cartridges from Grace and a dichloromethane/methanol gradient solvent equipped with ELSD and UV detectors at 254 and $280 \mathrm{~nm}$.

Mass spectroscopy analyses were performed by the Centre d'Etudes Structurales et d'Analyses des Molécules (CESAMO) in Bordeaux. The measurements were carried out on a TOF mass spectrometer AccuTOF GCv using an FD emitter with an emitter voltage of $10 \mathrm{kV}$. One to two microliters solution of the compound is deposited on a $13 \mathrm{~mm}$ emitter wire.

High-performance liquid chromatography (HPLC) was performed using a Spectra system instrument fitted with a Phenomenex Luna $5 \mu$ C18 100A column and compounds were detected with SpectraSYSTEM UV2000 from Thermo Separation Products. These analyses were performed with acetonitrile/water.

Differential Scanning Calorimetry (DSC) measurements were performed on DSC Q100 (TA Instruments). The sample was heated from $-50{ }^{\circ} \mathrm{C}$ to $220^{\circ} \mathrm{C}$ at a rate of $10{ }^{\circ} \mathrm{C} \cdot \mathrm{min}^{-1}$. Consecutive cooling and second heating run were also performed at $10{ }^{\circ} \mathrm{C} \cdot \mathrm{min}^{-1}$. The glass transition temperatures and melting points were calculated from the second heating run.

Dynamic Mechanical Analysis (DMA) measurements were performed on DMA-RSA3 system from TA instruments. The three point bending sample (width $=2 \mathrm{~mm}$; thickness $=2 \mathrm{~mm}$ and length of fixed section $=10 \mathrm{~mm}$ ) was heated from $25^{\circ} \mathrm{C}$ to $220^{\circ} \mathrm{C}$ at a heating rate of $5^{\circ} \mathrm{C} \cdot \mathrm{min}^{-1}$. The measurements were performed in a 3-point bending mode at a frequency of $1 \mathrm{~Hz}$, an initial static force of $0.5 \mathrm{~N}$ and a strain sweep of $0.01 \%$.

Thermogravimetric analyses (TGA) were performed on TGAQ50 system from TA instruments at a heating rate of $10{ }^{\circ} \mathrm{C} \cdot \mathrm{min}^{-1}$ under air atmosphere.

Tensile test were performed on MTS QTest 25 system. The measurements were performed on standardized dog-bone samples (width $=2 \mathrm{~mm}$; thickness $=2 \mathrm{~mm}$ and length of fixed section $=12 \mathrm{~mm}$ ) using a $500 \mathrm{~N}$ load cell and a crosshead speed of $1 \mathrm{~mm} \mathrm{~min}^{-1}$.

Rheological properties were assessed on Anton Paar MCR 301 stress controlled rheometer. Temperature was controlled on the bottom plate by Peltier effect. The geometry used for the measurement was a plate-plate $(25 \mathrm{~mm})$.

\section{Procedure for dimerization of vanillin}

Divanillin. A solution of vanillin $(1.5 \mathrm{~g})$ in acetone $(20 \mathrm{~mL})$ was added to NaOAc buffer $(180 \mathrm{~mL}, 0.1 \mathrm{M}, \mathrm{pH} 5.0)$. The solution was saturated in $\mathrm{O}_{2}$ for $5 \mathrm{~min}$. Laccase from Trametes versicolor $(20 \mathrm{U}, 12.4 \mathrm{mg})$ was added and the reaction was stirred at room temperature for $24 \mathrm{~h}$. The precipitate was filtered off and the product dried overnight at $80{ }^{\circ} \mathrm{C}$ under vacuum. Yield: $90 \%$.

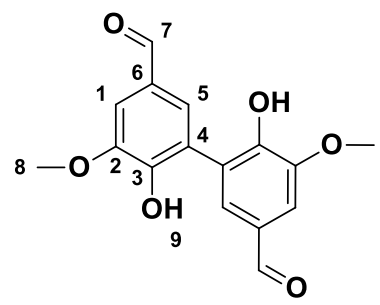

${ }^{1} \mathrm{H}$ NMR (400 MHz, DMSO, $\left.\delta(\mathrm{ppm})\right): \delta 9.81\left(\mathrm{~s}, \mathrm{H}_{7}\right), 7.43(\mathrm{~s}$, $\left.\mathrm{H}_{1}, \mathrm{H}_{5}\right), 3.93\left(\mathrm{~s}, \mathrm{H}_{8}\right)$.

${ }^{13} \mathrm{C}$ NMR (400 MHz, DMSO, $\left.\delta(\mathrm{ppm})\right): \delta 191.62\left(\mathrm{~s}, \mathrm{C}_{7}\right), 150.88$ $\left(\mathrm{s}, \mathrm{C}_{3}\right), 148.61\left(\mathrm{~s}, \mathrm{C}_{2}\right), 128.64\left(\mathrm{~s}, \mathrm{C}_{6}\right), 128.21\left(\mathrm{~s}, \mathrm{C}_{4}\right), 125.02$ (s, $\left.C_{5}\right), 109.6\left(s, C_{1}\right), 56.25\left(C_{8}\right)$.

\section{Procedure for reduction of divanillin}

Divanillyl alcohol. $20 \mathrm{mmol}$ of divanillin $(\approx 6 \mathrm{~g}$ ) were dissolved in $100 \mathrm{~mL}$ of $\mathrm{NaOH}(0.5 \mathrm{M})$. The flask was put in an ice bath and $3.6 \mathrm{~g}$ of sodium borohydride $(100 \mathrm{mmol})$ were added slowly. Then, the mixture was stirred at room temperature for $30 \mathrm{~min}$. The solution was acidified with $\mathrm{HCl}$ to $\mathrm{pH}$ 7. The precipitate was filtered off and the product dried overnight at $80^{\circ} \mathrm{C}$ under vacuum. Yield: $90 \%$. 


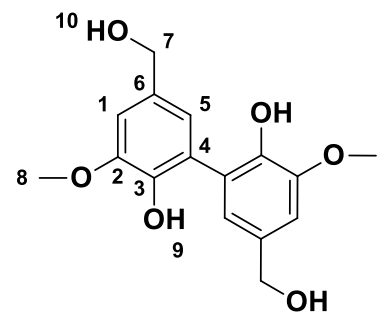

${ }^{1} \mathrm{H}$ NMR $(400 \mathrm{MHz}, \mathrm{DMSO}, \delta(\mathrm{ppm})): \delta 8.22(\mathrm{~s}, \mathrm{H} 9), 6.88(\mathrm{~s}$, $H 5), 6.67(s, H 1), 5.01(t, H 10), 4.41(d, H 7), 3.82(s, H 8)$.

${ }^{13} \mathrm{C}$ NMR (400 MHz, DMSO, $\delta$ (ppm)): $\delta 147.94$ (s, C3), 142.77 (s, C2), 133.08 (s, C6), 125.92 (s, C4), 121.83 (s, C5), 109.50 (s, C1), $63.38(\mathrm{~s}, \mathrm{C} 7), 56.25(\mathrm{~s}, \mathrm{C} 8)$.

\section{Procedure for glycidylation of divanillyl alcohol}

Diglycidylether of divanillin. $3 \mathrm{~g}$ of divanillyl alcohol $(10 \mathrm{mmol})$ were dissolved in $15 \mathrm{~mL}$ of epichlorohydrin $(0,2 \mathrm{~mol}) .0,3 \mathrm{~g}$ of tetrabutylammonium chloride (TEBAC) $(0.95 \mathrm{mmol})$ were added and the solution was stirred at $80^{\circ} \mathrm{C}$ for $1 \mathrm{~h} 30.8 \mathrm{~mL}$ of a solution of $\mathrm{NaOH}(5 \mathrm{M})(40 \mathrm{mmol})$ were added and the solution was stirred at room temperature for $1 \mathrm{~h}$. The product was extracted with dichloromethane and washed with water. Dichloromethane and epichlorohydrin were removed from the organic phase under vacuum. Further purification was achieved by flash chromatography using dichloromethane/methanol gradient solvent (95/5). Yield: $80 \%$.

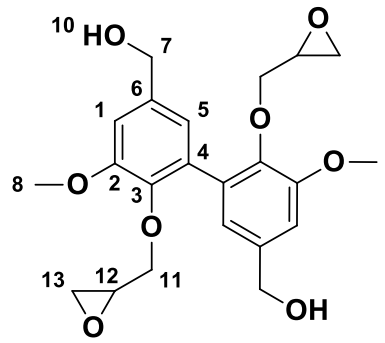

${ }^{1} \mathrm{H}$ NMR (400MHz, DMSO, $\left.\delta(\mathrm{ppm})\right): \delta 7.0\left(\mathrm{~s}, \mathrm{H}_{5}\right), 6.71\left(\mathrm{~s}, \mathrm{H}_{1}\right)$, $5.16\left(t, H_{10}\right), 4.47\left(d, H_{7}\right), 3.88\left(m, H_{11}\right), 3.83\left(s, H_{8}\right), 3.74(m$ $\left.\mathrm{H}_{11 \mathrm{~b}}\right), 2.95\left(\mathrm{~m}, \mathrm{H}_{12}\right), 2.6\left(\mathrm{t}, \mathrm{H}_{13}\right), 2.36\left(\mathrm{t}, \mathrm{H}_{13 \mathrm{~b}}\right)$.

${ }^{13} \mathrm{C}$ NMR (400MHz, DMSO, $\delta$ (ppm)): $\delta 152.33$ (s, $\left.\mathrm{C}_{3}\right), 144.47$ (s, $\left.\mathrm{C}_{2}\right), 138.26\left(\mathrm{~s}, \mathrm{C}_{6}\right), 132.59\left(\mathrm{~s}, \mathrm{C}_{4}\right), 120.86\left(\mathrm{~s}, \mathrm{C}_{5}\right), 110.79\left(\mathrm{~s}, \mathrm{C}_{1}\right)$ $74.22\left(\mathrm{~s}, \mathrm{C}_{11}\right), 63.14\left(\mathrm{~s}, \mathrm{C}_{7}\right), 56.18\left(\mathrm{~s}, \mathrm{C}_{8}\right), 50.53\left(\mathrm{~s}, \mathrm{C}_{12}\right), 43.97(\mathrm{~s}$, C13).

HRMS (m/z, ES+, $\left.\left[\mathrm{M}+\mathrm{Na}^{+}\right]\right)$: calculated: 441.1519; found: 441.1505 .

Triglycidylether of divanillyl alcohol. $3 \mathrm{~g}$ of divanillyl alcohol (10 mmol) were dissolved in $15 \mathrm{~mL}$ of epichlorohydrin $(0,2$ mol). $0,3 \mathrm{~g}$ of tetrabutylammonium chloride (TEBAC) $(0.95$ $\mathrm{mmol}$ ) were added and the solution was stirred at $80{ }^{\circ} \mathrm{C}$ for $1 \mathrm{~h} 30.8 \mathrm{~mL}$ of a solution of $\mathrm{NaOH}(5 \mathrm{M})(40 \mathrm{mmol})$ were added and the solution was stirred at room temperature for $4 \mathrm{~h} 30$. The product was extracted with dichloromethane and washed with water. Dichloromethane and epichlorohydrin were removed from the organic phase under vacuum. Further purification was achieved by flash chromatography using dichloromethane/methanol gradient solvent (95/5).

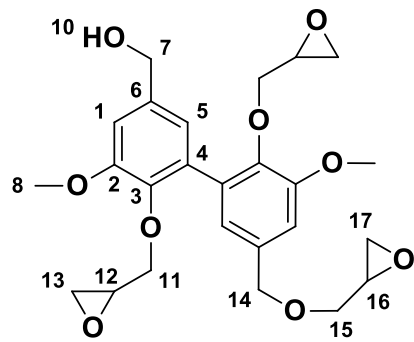

${ }^{1} \mathrm{H}$ NMR (400MHz, DMSO, $\left.\delta(\mathrm{ppm})\right): \delta 7.01\left(\mathrm{~s}, \mathrm{H}_{5}\right), 6.75\left(\mathrm{~s}, \mathrm{H}_{1}\right)$, $5.18\left(\mathrm{t}, \mathrm{H}_{10}\right), 4.47\left(\mathrm{~d}, \mathrm{H}_{7} \mathrm{H}_{14}\right), 3.92\left(\mathrm{~m}, \mathrm{H}_{11}\right), 3.84\left(\mathrm{~s}, \mathrm{H}_{8}\right), 3.76(\mathrm{~m}$, $\left.\mathrm{H}_{11 \mathrm{~b}}\right), 3.69\left(\mathrm{~m}, \mathrm{H}_{15}\right), 3.29\left(\mathrm{~m}, \mathrm{H}_{15 \mathrm{~b}}\right), 3.14\left(\mathrm{~m}, \mathrm{H}_{16}\right), 2.97\left(\mathrm{~m}, \mathrm{H}_{12}\right)$, $2.72\left(m, H_{17}\right), 2.6\left(m, H_{13}\right), 2.5\left(m, H_{17 b}\right), 2.36\left(m, H_{13 b}\right)$.

${ }^{13} \mathrm{C}$ NMR (400MHz, DMSO, $\left.\delta(\mathrm{ppm})\right): \delta 152.02\left(\mathrm{~s}, \mathrm{C}_{3^{\prime}}\right), \delta 151.89$ $\left(\mathrm{s}, \mathrm{C}_{3}\right), 144.38\left(\mathrm{~s}, \mathrm{C}_{2^{\prime}}\right), 143.68\left(\mathrm{~s}, \mathrm{C}_{2}\right), 138.12\left(\mathrm{~s}, \mathrm{C}_{6^{\prime}}\right), 133.39(\mathrm{~s}$, $\left.\mathrm{C}_{6}\right), 132.06\left(\mathrm{~s}, \mathrm{C}_{4^{\prime}}\right), 131.76\left(\mathrm{~s}, \mathrm{C}_{4}\right), 121.78\left(\mathrm{~s}, \mathrm{C}_{5^{\prime}}\right), 120.26\left(\mathrm{~s}, \mathrm{C}_{5}\right)$, 111.55 (s, C $\left.\mathrm{C}^{\prime}\right), 110.46\left(\mathrm{~s}, \mathrm{C}_{1}\right), 73.85$ (s, $\left.\mathrm{C}_{14}\right), 71.81\left(\mathrm{~s}, \mathrm{C}_{15}\right), 70.79$ $\left(\mathrm{s}, \mathrm{C}_{11}\right), 62.67\left(\mathrm{~s}, \mathrm{C}_{7}\right), 55.90\left(\mathrm{~s}, \mathrm{C}_{8}\right), 50.42\left(\mathrm{~s}, \mathrm{C}_{12}\right), 50.16\left(\mathrm{~s}, \mathrm{C}_{16}\right)$, $43.42\left(\mathrm{~s}, \mathrm{C}_{13} \mathrm{C}_{17}\right)$.

HRMS (m/z, ES+, $\left.\left[\mathrm{M}+\mathrm{Na}^{+}\right]\right)$: calculated: 497.1782; found: 497.1770 .

Tetraglycidylether of divanillyl alcohol. $3 \mathrm{~g}$ of divanillyl alcohol (10 mmol) were dissolved in $15 \mathrm{~mL}$ of epichlorohydrin $(0,2$ mol). $0,3 \mathrm{~g}$ of tetrabutylammonium chloride (TEBAC) (0.95 mmol) were added and the solution was stirred at $80{ }^{\circ} \mathrm{C}$ for $1 \mathrm{~h} 30.16 \mathrm{~mL}$ of a solution of $\mathrm{NaOH}(10 \mathrm{M})(160 \mathrm{mmol})$ were added and the solution was stirred at room temperature for $24 \mathrm{~h}$. The product was extracted with dichloromethane and washed with water. Dichloromethane and epichlorohydrin were removed from the organic phase under vacuum. Further purification was achieved by flash chromatography using dichloromethane/methanol gradient solvent. Yield: $80 \%$.

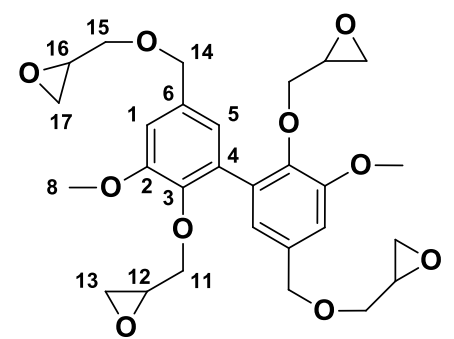

${ }^{1} \mathrm{H}$ NMR $(400 \mathrm{MHz}, \mathrm{DMSO}, \delta(\mathrm{ppm})): \delta 7.02\left(\mathrm{~s}, \mathrm{H}_{5}\right), 6.76\left(\mathrm{~s}, \mathrm{H}_{1}\right)$, $4.50\left(\mathrm{~s}, \mathrm{H}_{14}\right), 3.92\left(\mathrm{~m}, \mathrm{H}_{11}\right), 3.86\left(\mathrm{~s}, \mathrm{H}_{8}\right), 3.76\left(\mathrm{~m}, \mathrm{H}_{11 \mathrm{~b}}\right), 3.70(\mathrm{~m}$, $\left.\mathrm{H}_{15}\right), 3.28\left(\mathrm{~m}, \mathrm{H}_{15 b}\right), 3.14\left(\mathrm{~m}, \mathrm{H}_{16}\right), 2.97\left(\mathrm{~m}, \mathrm{H}_{12}\right), 2.73\left(\mathrm{~m}, \mathrm{H}_{17}\right)$, $2.60\left(\mathrm{~m}, \mathrm{H}_{13}\right), 2.55\left(\mathrm{~m}, \mathrm{H}_{17 \mathrm{~b}}\right), 2.35\left(\mathrm{~m}, \mathrm{H}_{13 \mathrm{~b}}\right)$.

${ }^{13} \mathrm{C}$ NMR (400MHz, DMSO, $\delta$ (ppm)): $\delta 152.10$ (s, C 3 ), 144.51 (s, $\left.\mathrm{C}_{2}\right), 133.51\left(\mathrm{~s}, \mathrm{C}_{6}\right), 131.81\left(\mathrm{~s}, \mathrm{C}_{4}\right), 121.83\left(\mathrm{~s}, \mathrm{C}_{5}\right), 111.52\left(\mathrm{~s}, \mathrm{C}_{1}\right)$, $73.77\left(\mathrm{~s}, \mathrm{C}_{14}\right), 71.90\left(\mathrm{~s}, \mathrm{C}_{15}\right), 63.14\left(\mathrm{~s}, \mathrm{C}_{11}\right), 55.79\left(\mathrm{~s}, \mathrm{C}_{8}\right), 50.30$ $\left(\mathrm{s}, \mathrm{C}_{12}\right), 50.03\left(\mathrm{~s}, \mathrm{C}_{16}\right), 43.44\left(\mathrm{~s}, \mathrm{C}_{13} \mathrm{C}_{17}\right)$.

HRMS (m/z, ES+, $\left.\left[\mathrm{M}+\mathrm{Na}^{+}\right]\right)$: calculated: 553.2044; found: 553.2064 


\section{Procedure for tensile testing samples preparation}

Epoxy prepolymers were mixed vigorously with stoichiometric amount of IPDA. The mixture was poured into a silicon mould. Samples were degased at room temperature or with a minimum of heat under vacuum. Silicon mould was then heated in an oven during $1 \mathrm{~h}$ at $100{ }^{\circ} \mathrm{C}$ followed by $1 \mathrm{~h} 140^{\circ} \mathrm{C}$. The full conversion were checked by DSC analysis prior to further mechanical test.

\section{Procedure for flaming test}

Cured samples of epoxy thermosets were putted in direct contact with flame from a blowtorch during 3 seconds. This procedure was repeated until the combustion of the sample starts.

\section{Acknowledgments}

The authors thank Gerard Dimier for the DSC and DMA analyses. This study was financially supported by ArianeGroup. The authors would also thank Equipex Xyloforest ANR-10EQPX-16 XYLOFOREST for flash chromatography.

\section{References}

1 R. Auvergne, S. Caillol, G. David, B. Boutevin and J. Pascault, Chem. Rev., 2014, 114, 1082-1115.

2 J.-M. Raquez, M. Deléglise, M.-F. Lacrampe and P. Krawczak, Prog. Polym. Sci., 2010, 35, 487-509.

3 European Chemical Agency, Committee for Risk Assessment RAC proposing harmonised classification and labelling at EU level of Bisphenol A, 2014.

4 European Food Safety Authority, Bisphenol A, public consultation, exposure assessment, toxicity, health risks, 2015.

5 M. Bondesson, J. Jönsson, I. Pongratz, N. Olea, J. P. Cravedi, D. Zalko, H. Håkansson, K. Halldin, D. Di Lorenzo, C. Behl, D. Manthey, P. Balaguer, B. Demeneix, J. B. Fini, V. Laudet and J. Å. Gustafsson, Reprod. Toxicol., 2009, 28, 563-567. L. N. Vandenberg, R. Hauser, M. Marcus, N. Olea and W. V. Welshons, Reprod. Toxicol., 2007, 24, 139-177.

7 J. H. Kang, F. Kondo and Y. Katayama, Toxicology, 2006, 226, 79-89.

8 H. H. Le, E. M. Carlson, J. P. Chua and S. M. Belcher, Toxicol. Lett., 2008, 176, 149-156.

9 R. Eggert, R. F. Aguilera, G. Lagos and J. Tilton, Energy J., 2009, 30, 141-174.

10 J. C. Ronda, G. Lligadas, M. Galià and V. Cádiz, Eur. J. Lipid Sci. Technol., 2011, 113, 46-58.

11 U. Biermann, W. Friedt, S. Lang, W. Lhs, G. Machmller, U. O. Metzger, M. R. Gen. Klaas, H. J. Schfer and M. P. Schneider, in Biorefineries-Industrial Processes and Products, Wiley-VCH Verlag GmbH, Weinheim, Germany, 2000, vol. 39, pp. 253-289.

12 Hi-Tek Polymers Inc., US5227453 A, 1993.

13 S. Dirlikov, I. Frischinger, M. S. Islam and T. J. Lepkowski, in Biotechnology and Polymers, ed. C. G. Gebelein, Springer

US, Boston, MA, 1991, pp. 79-93.

14

15

16
L. Deng, C. Ha, C. Sun, B. Zhou, J. Yu, M. Shen and J. Mo, Ind. Eng. Chem. Res., 2013, 52, 13233-13240.

M. Chrysanthos, J. Galy and J.-P. Pascault, Polymer (Guildf)., 2011, 52, 3611-3620.

F. Jaillet, E. Darroman, A. Ratsimihety, R. Auvergne, B. Boutevin and S. Caillol, Eur. J. Lipid Sci. Technol., 2014, 116, 63-73.

A. Maiorana, S. Spinella and R. a Gross, Biomacromolecules, 2015, 16, 1021-31.

A. Patel, A. Maiorana, L. Yue, R. A. Gross and I. ManasZloczower, Macromolecules, 2016, 49, 5315-5324.

C. Aouf, H. Nouailhas, M. Fache, S. Caillol, B. Boutevin and H. Fulcrand, Eur. Polym. J., 2013, 49, 1185-1195.

K. Hofmann and W. G. Glasser, J. Wood Chem. Technol., 1993, 13, 73-95.

K. Hofmann and W. Glasser, Macromol. Chem. Phys., 1994, 195, 65-80.

C. Asada, S. Basnet, M. Otsuka, C. Sasaki and Y. Nakamura, Int J Biol Macromol, 2015, 74, 413-419.

P. C. R. Pinto and E. A. Borges, eds. C. Baskar, S. Baskar and R. S. Dhillon, Springer Berlin Heidelberg, Berlin, Heidelberg, 2012.

H.-R. Bjørsvik and F. Minisci, Org. Process Res. Dev., 1999, 3, 330-340.

E. A. B. da Silva, M. Zabkova, J. D. Araújo, C. A. Cateto, M. F. Barreiro, M. N. Belgacem and A. E. Rodrigues, Chem. Eng. Res. Des., 2009, 87, 1276-1292.

M. Fache, B. Boutevin and S. Caillol, ACS Sustain. Chem. Eng., 2016, 4, 35-46.

M. Fache, B. Boutevin and S. Caillol, Eur. Polym. J., 2015, 68, 488-502.

M. Fache, R. Auvergne, B. Boutevin and S. Caillol, Eur. Polym. J., 2015, 67, 527-538.

M. Fache, A. Viola, R. Auvergne, B. Boutevin and S. Caillol, Eur. Polym. J., 2015, 68, 526-535.

A. S. Amarasekara and M. A. Hasan, Polym. Sci. Ser. B, 2016, 1-6.

B. G. Harvey, A. J. Guenthner, H. a. Meylemans, S. R. L. Haines, K. R. Lamison, T. J. Groshens, L. R. Cambrea, M. C. Davis and W. W. Lai, Green Chem., 2015, 17, 1249-1258. M. Fache, B. Boutevin and S. Caillol, Green Chem., 2016, 18, 712-725.

S. R. L. Haines, K. R. Lamison, T. J. Groshens, L. R. Cambrea, M. C. Davis and W. W. Lai, Green Chem., 2015, 17, 12491258.

J. F. Stanzione III, J. M. Sadler, J. J. La Scala, K. H. Reno and R. P. Wool, Green Chem., 2012, 14, 2346.

C. Zhang, S. a. Madbouly and M. R. Kessler, Macromol. Chem. Phys., 2015, 216, 1816-1822.

A. Llevot, E. Grau, S. Carlotti, S. Grelier and H. Cramail, Polym. Chem., 2015, 6, 6058-6066.

S. Kobayashi and A. Makino, Chem. Rev., 2009, 109, 52885353.

A. Llevot, E. Grau, S. Carlotti, S. Grelier and H. Cramail, J. Mol. Catal. B Enzym., 2016, 125, 34-41.

A. Llevot, E. Grau, S. Carlotti, S. Grelier and H. Cramail, Macromol. Rapid Commun., 2016, 37, 9-28. 

Tetrahedron, 2013, 69, 1345-1353.

41 M. Fache, E. Darroman, V. Besse, R. Auvergne, S. Caillol and B. Boutevin, Green Chem., 2014, 16, 1987.

42 E. D. Hernandez, A. W. Bassett, J. M. Sadler, J. J. La Scala and J. F. Stanzione, ACS Sustain. Chem. Eng., 2016, 4, 4328-4339.

43 ASTM D 1002-05, Standards, 2005, 1-5.

44 H. Q. Pham and M. J. Marks, Ullmann's Encyclopedia of Industrial Chemistry, Wiley-VCH Verlag GmbH \& Co. KGaA, Weinheim, Germany, 2000.

45 J. Galy, A. Sabra and J. Pascault, Polym. Eng. Sci., 1986, 26, 1514-1523.

46 J. Charlesworth, J. Polym. Sci. Polym. Chem. Ed., 1980, 18, 621-628.

47 K. Dušek, M. Bleha and S. Luňák, J. Polym. Sci. Polym. Chem. Ed., 1977, 15, 2393-2400.

48 X. Wang and J. K. Gillham, J. Appl. Polym. Sci., 1991, 43, 2267-2277.

49 T. lijima, N. Yoshioka and M. Tomoi, Eur. Polym. J., 1992, 28, 573-581.

50 P. J. Flory, Polymer (Guildf)., 1979, 20, 1317-1320.

51 J. F. Gerard, J. Galy, J. P. Pascault, S. Cukierman and J. L. Halary, Polym. Eng. Sci., 1991, 31, 615-621. Y. C. Chiu, I. C. Chou, W. C. Tseng and C. C. M. Ma, Polym. Degrad. Stab., 2008, 93, 668-676.

53 M. Fache, C. Montérémal, B. Boutevin and S. Caillol, Eur. Polym. J., 2015, 73, 344-362.

54 M. M. Sain and C. Daneault, Polym. Degrad. Stab., 1996, 51, 67-75.

55 D. W. van Krevelen, Polymer (Guildf)., 1975, 16, 615-620. 


\section{Electronic Supplementary Information}

S1 - ${ }^{1} \mathrm{H}$ NMR spectrum of divanillin (DMSO-d6).
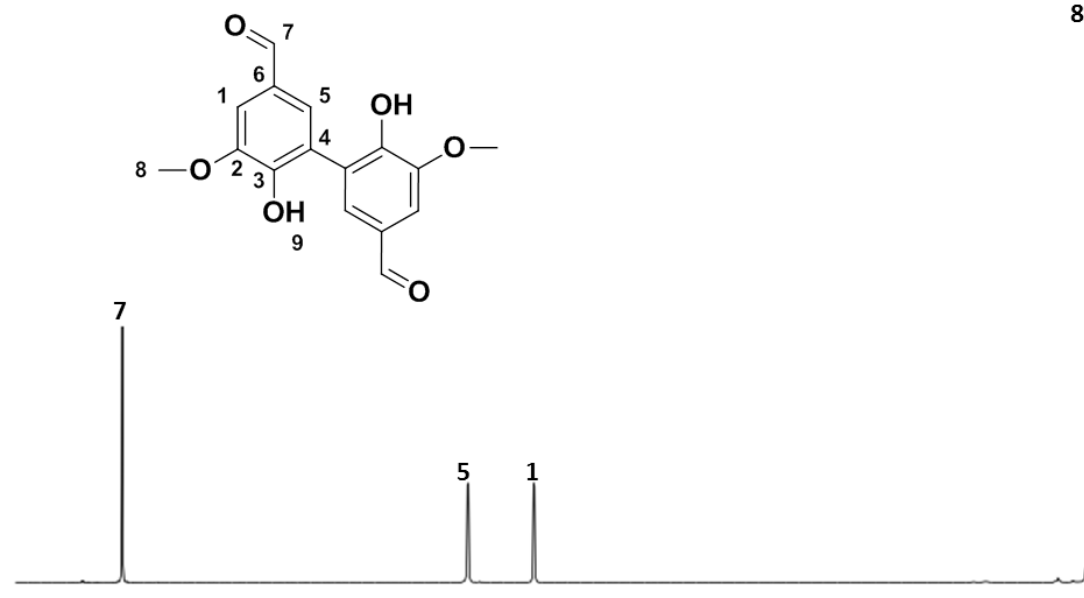

8

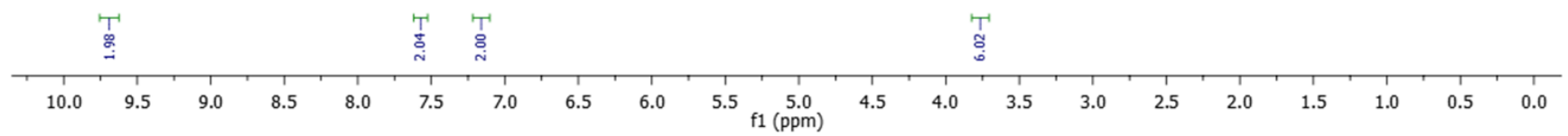

S2 $-{ }^{13} \mathrm{C}$ NMR spectrum of divanillin (DMSO-d6).
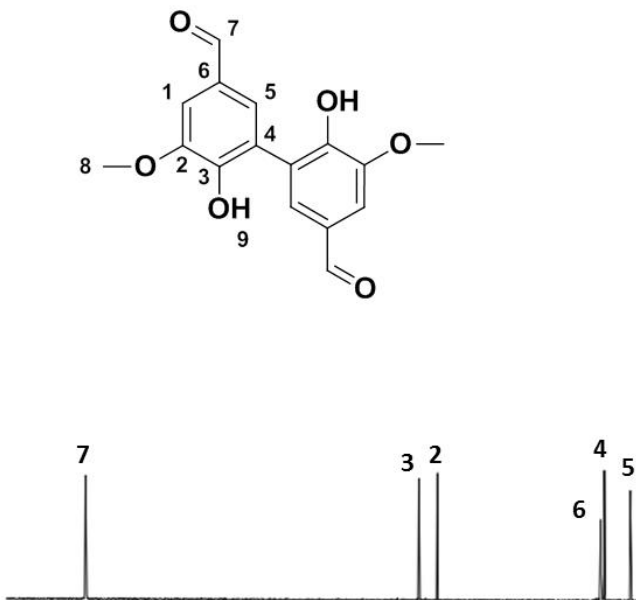

8
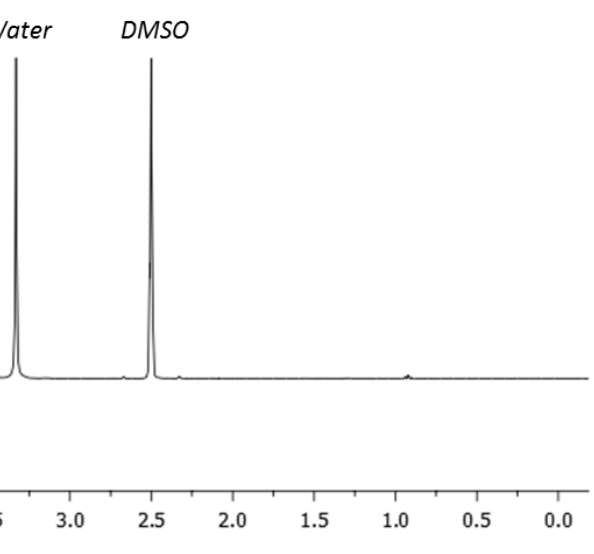
S3 - ${ }^{1} \mathrm{H}$ NMR spectrum of divanillyl alcohol (DMSO-d6).
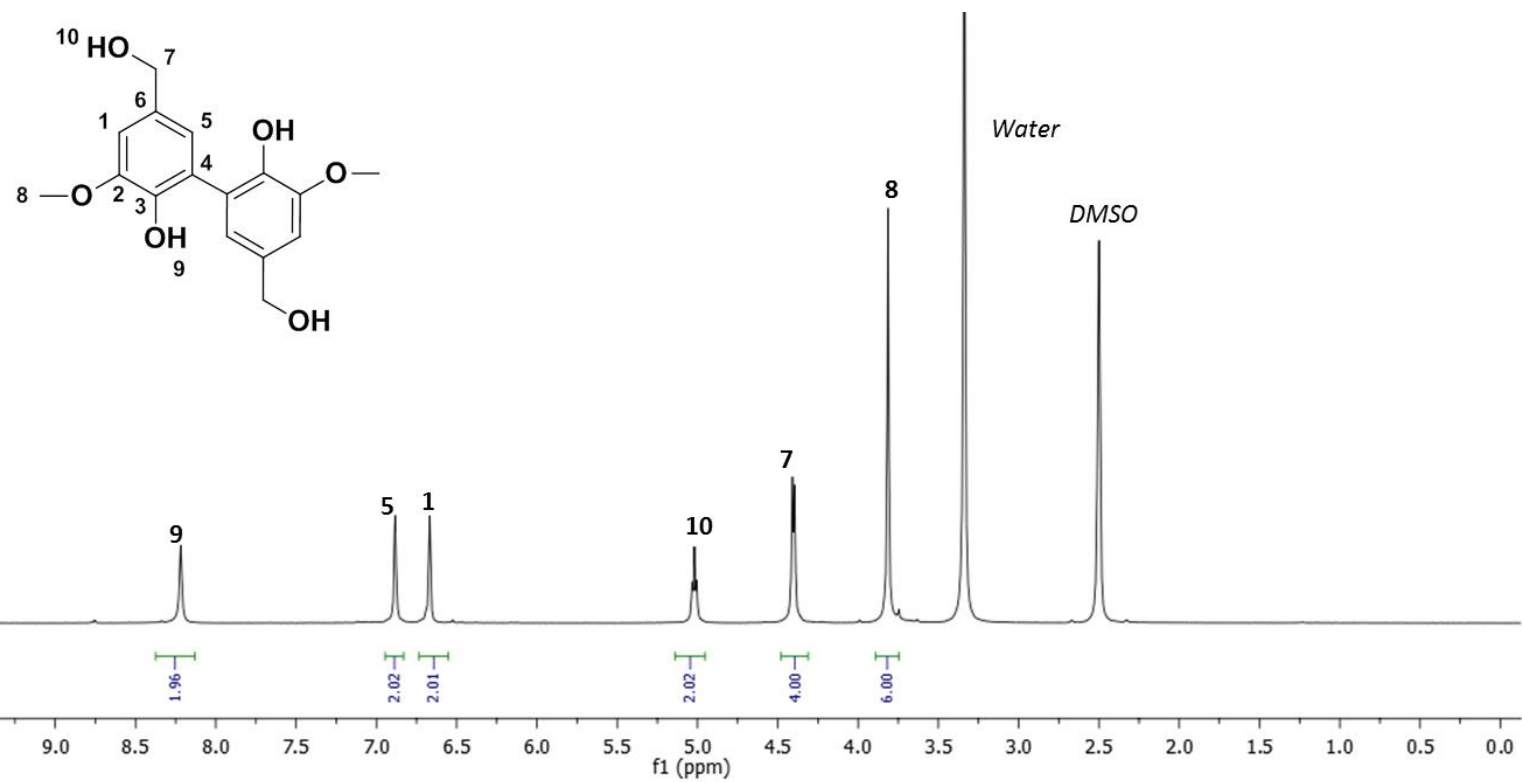

S4 $-{ }^{13} \mathrm{C}$ NMR spectrum of divanillyl alcohol (DMSO-d6).
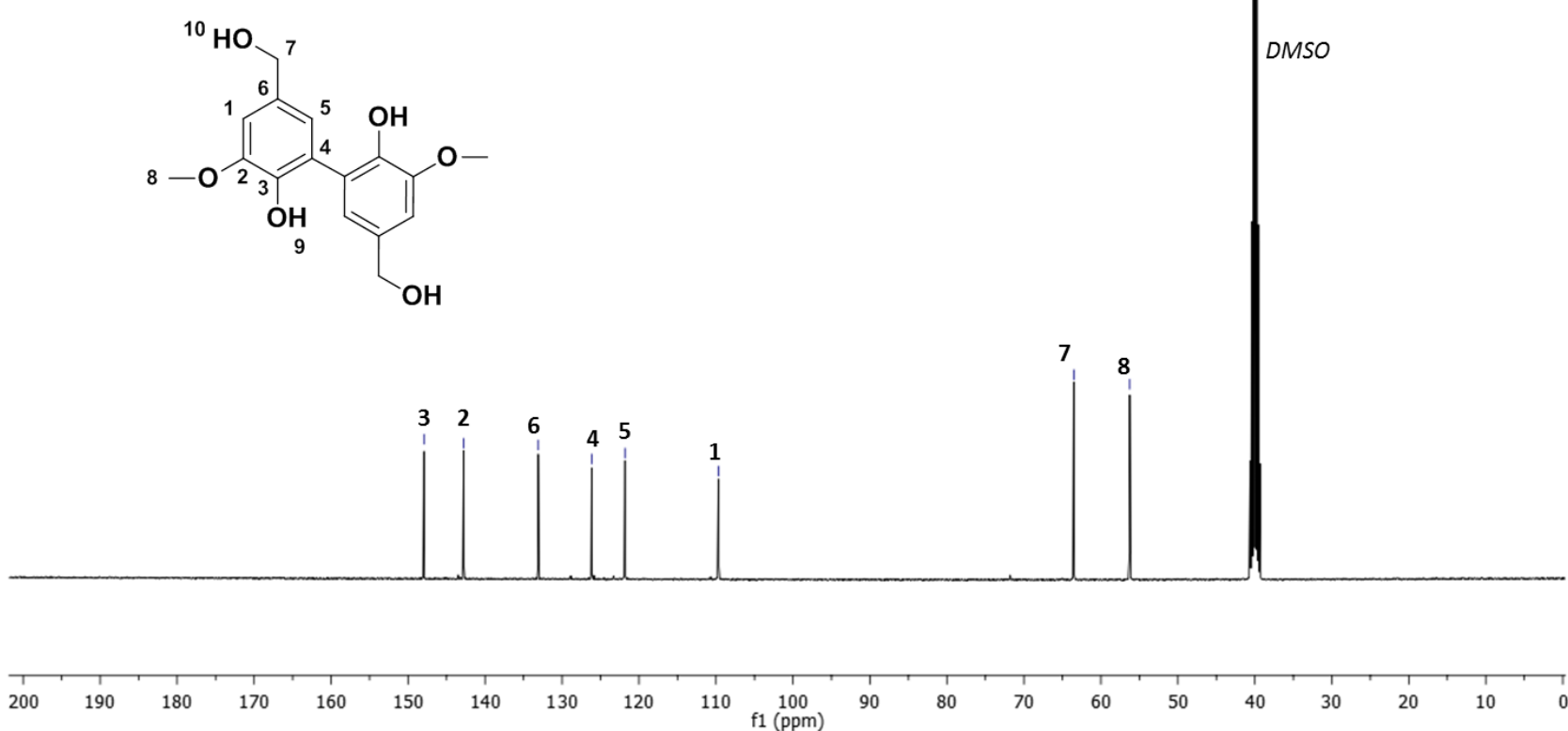
S5 - ${ }^{1} \mathrm{H}$ NMR spectrum of diglycidyl ether of divanillyl alcohol (DMSO-d6).

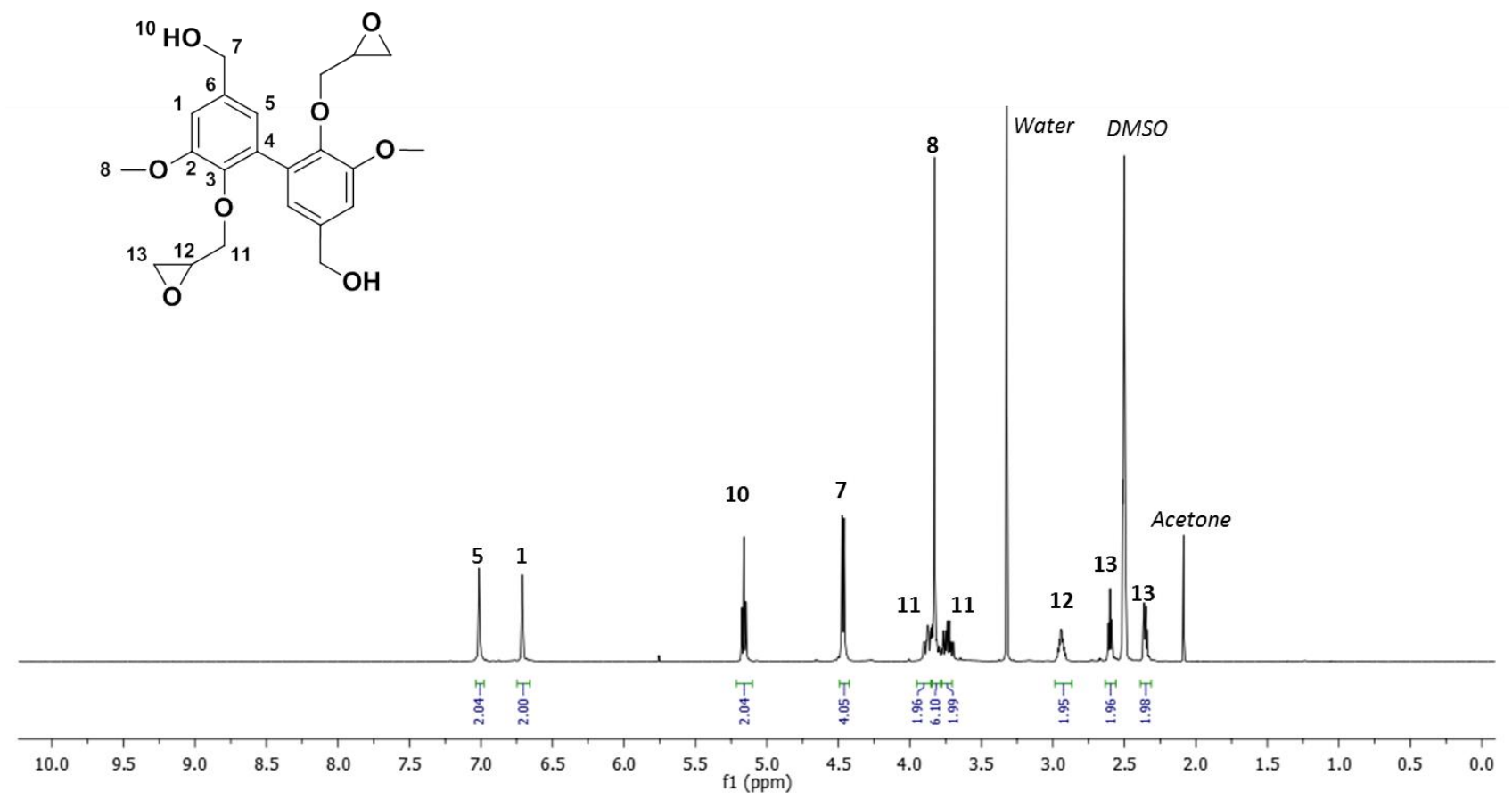

S6 $-{ }^{13} \mathrm{C}$ NMR spectrum of diglycidyl ether of divanillyl alcohol (DMSO-d6).<smiles>COc1cc(CO)cc(-c2cc(CO)cc(OC)c2OC[C@@H]2CO2)c1OCC1CO1</smiles>
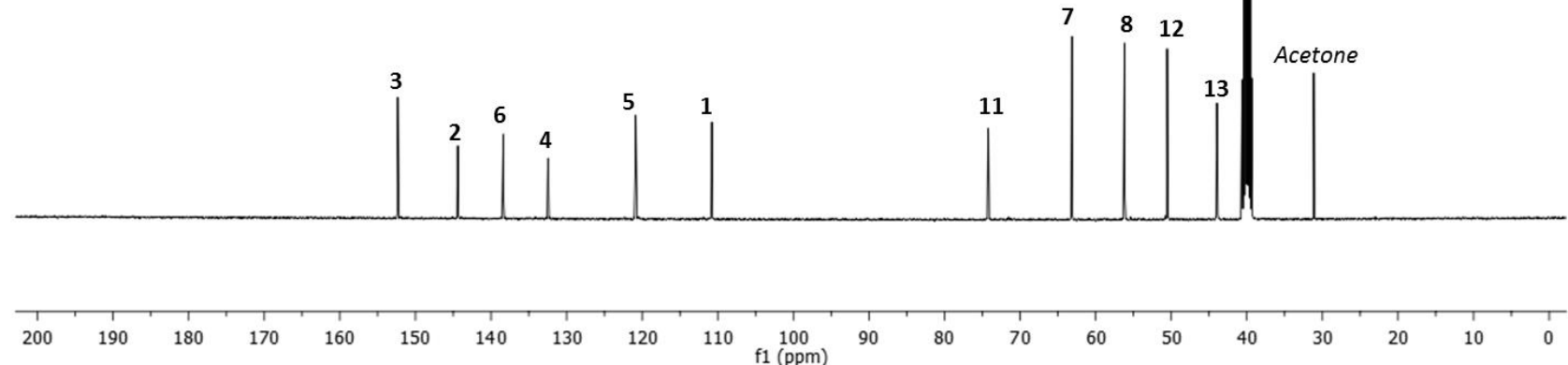
S7 - ${ }^{1} \mathrm{H}$ NMR spectrum of triglycidyl ether of divanillyl alcohol (DMSO-d6).
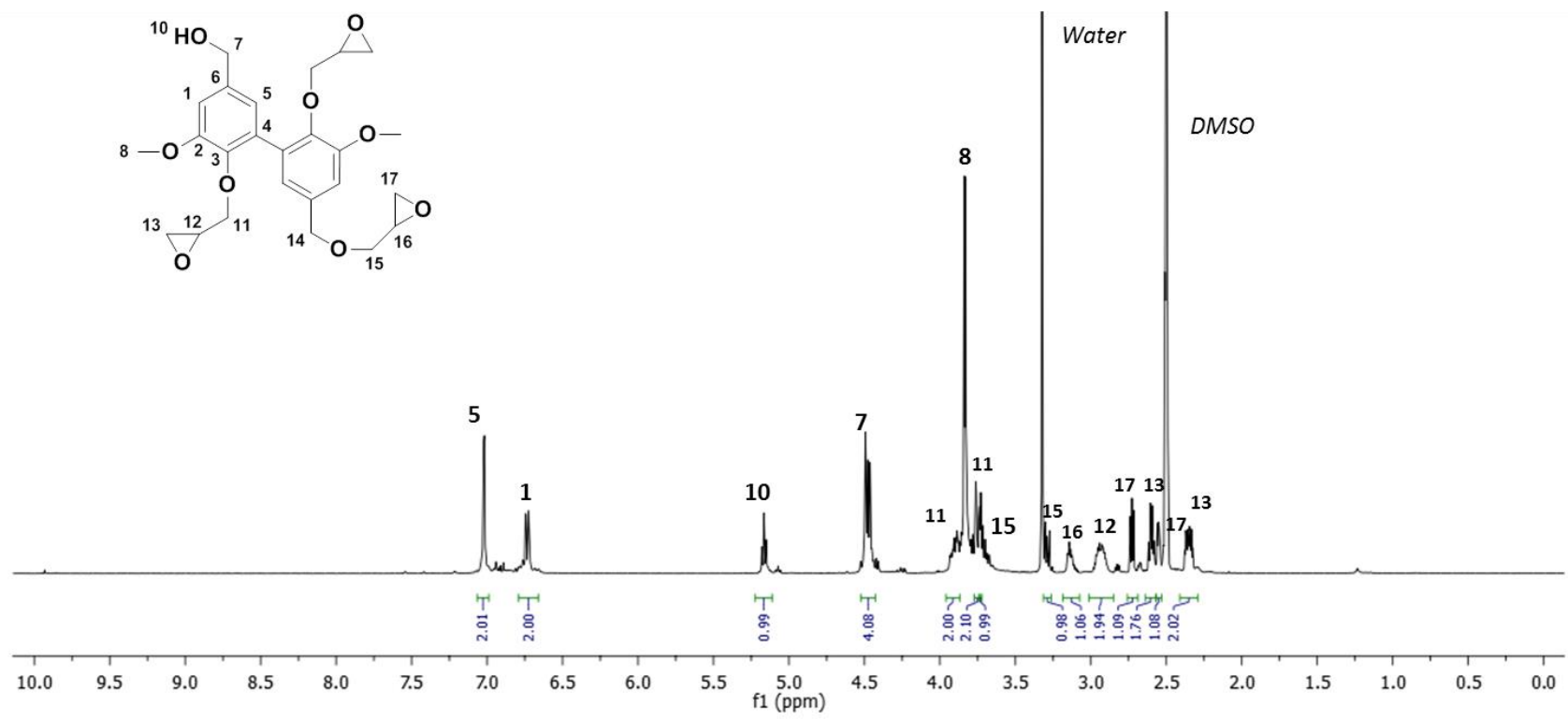

S8 $-{ }^{13} \mathrm{C}$ NMR spectrum of triglycidyl ether of divanillyl alcohol (DMSO-d6).
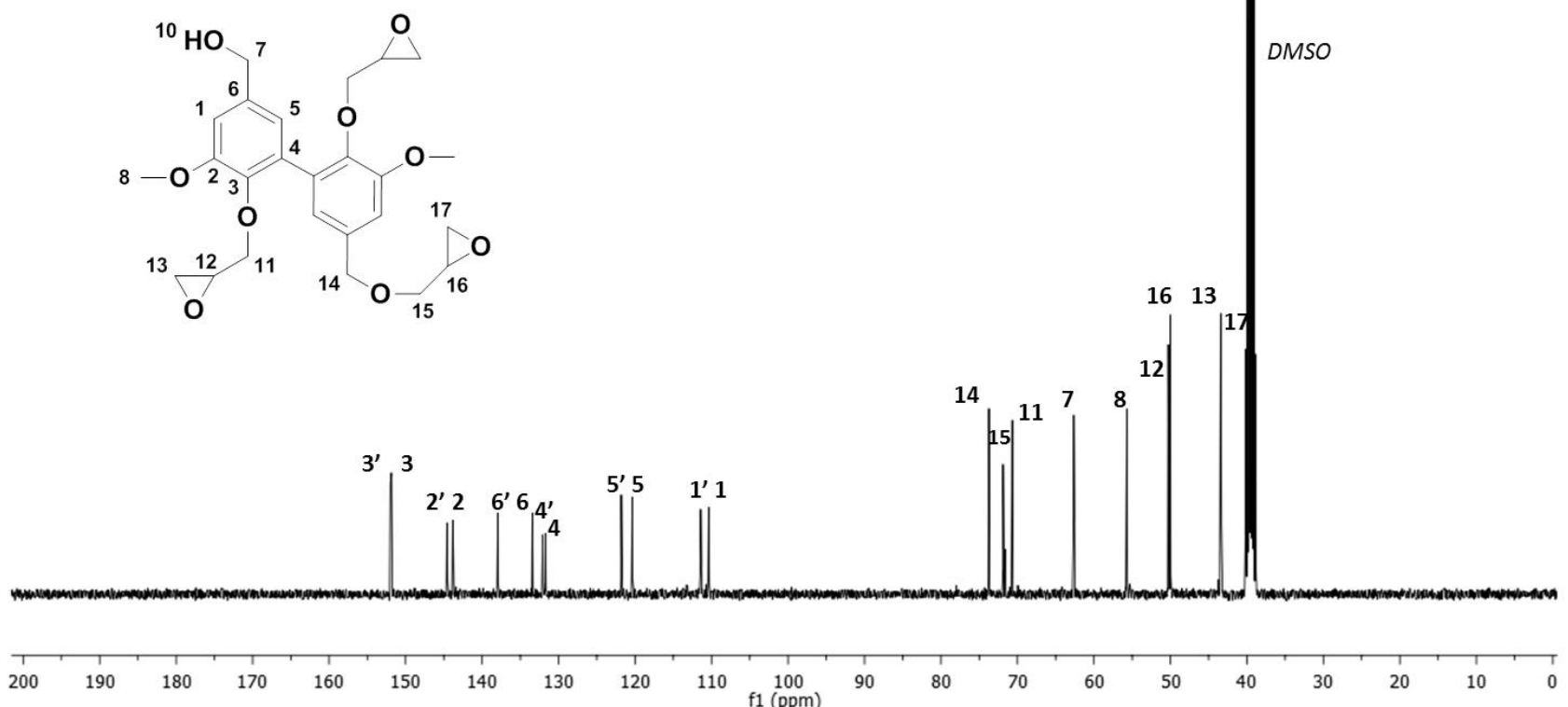
S9 - ${ }^{1} \mathrm{H}$ NMR spectrum of tetraglycidyl ether of divanillyl alcohol (DMSO- $d 6$ ).
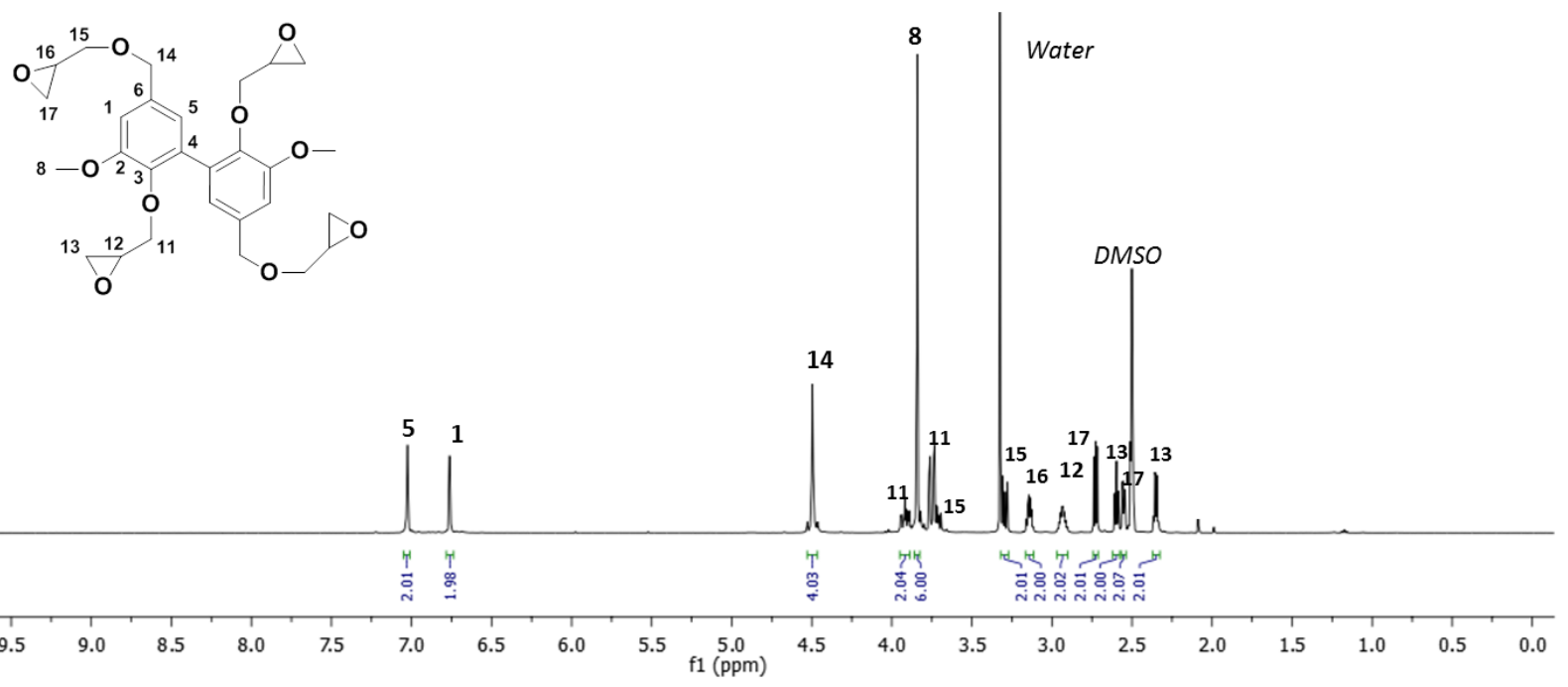

S10 $-{ }^{13} \mathrm{C}$ NMR spectrum of tetraglycidyl ether of divanillyl alcohol (DMSO- $d 6$ ).
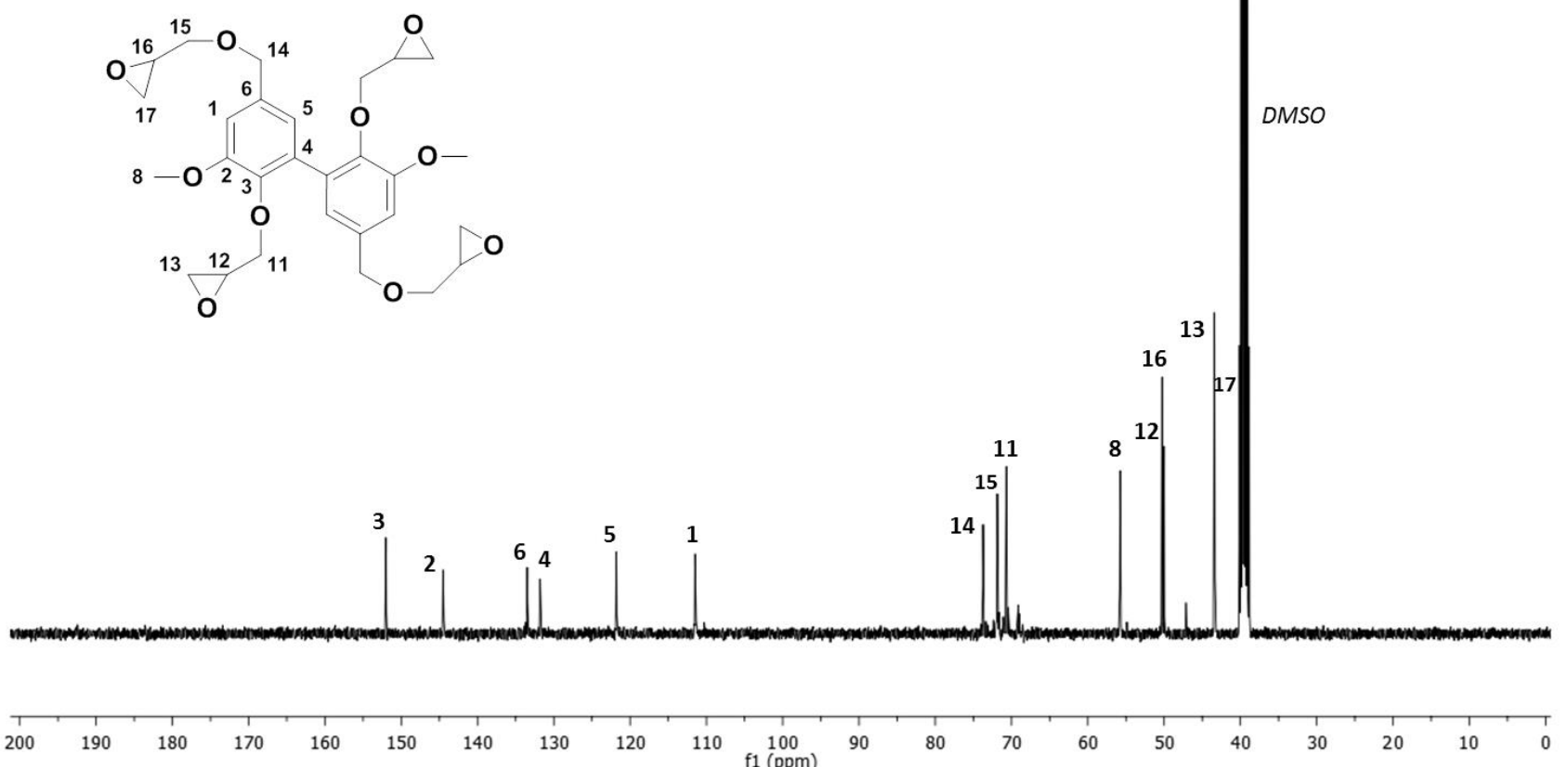
S11 - DSC Thermograms of (a)DGEBA, (b) DiGEDVA, (c) TriGEDVA and (d) TetraGEDVA cured with IPDA for $r=1$
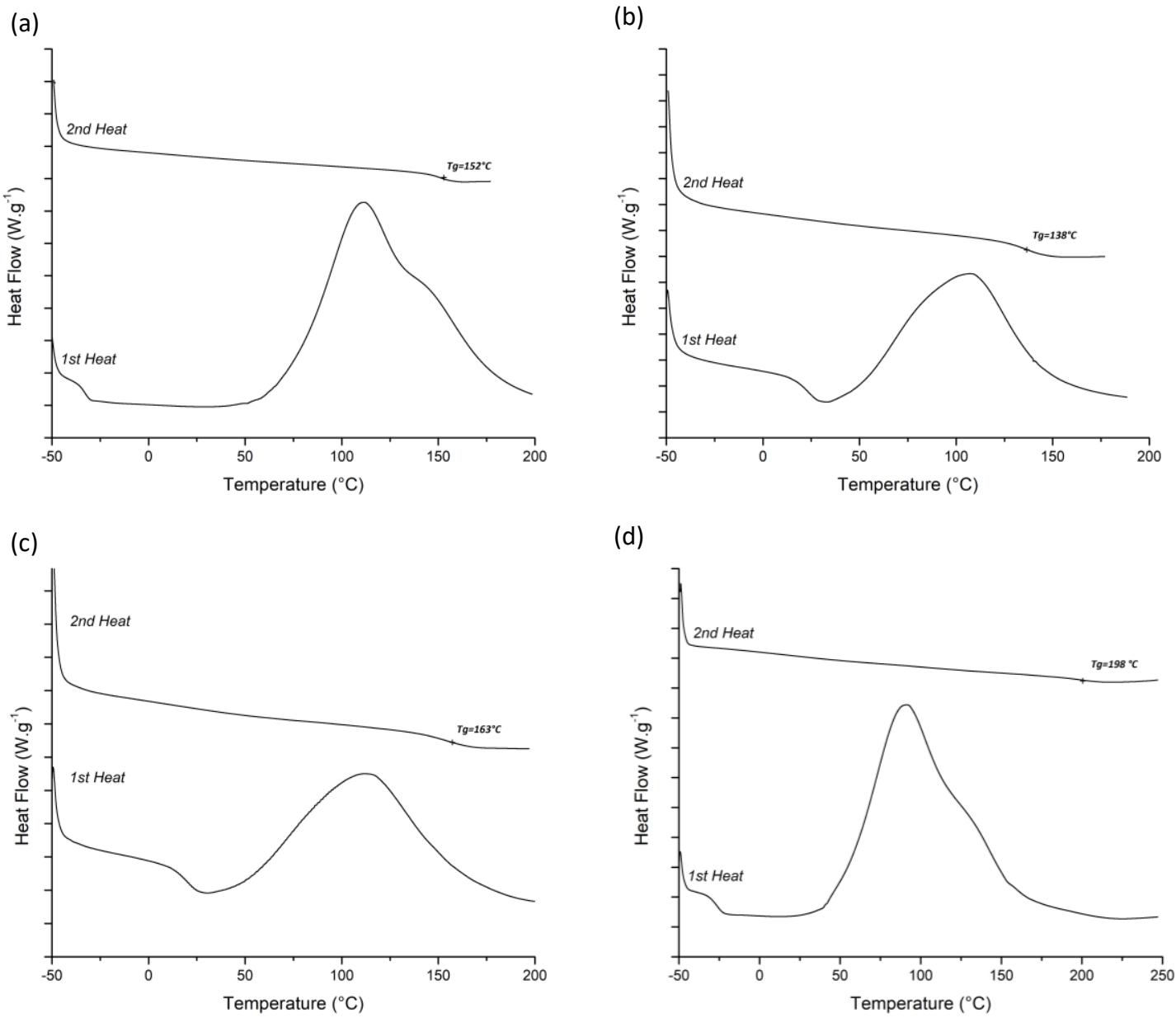
S12 - DMA traces of (a)DGEBA, (b) DiGEDVA, (c) TriGEDVA and (d) TetraGEDVA cured with IPDA for $r=1$

(a)

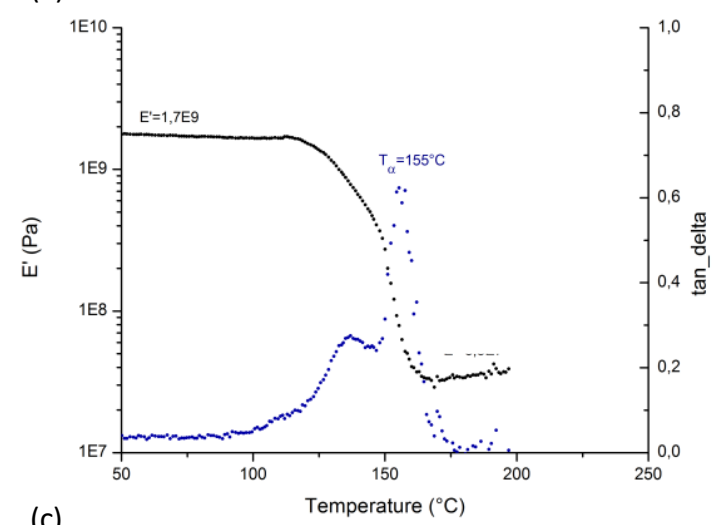

(c)

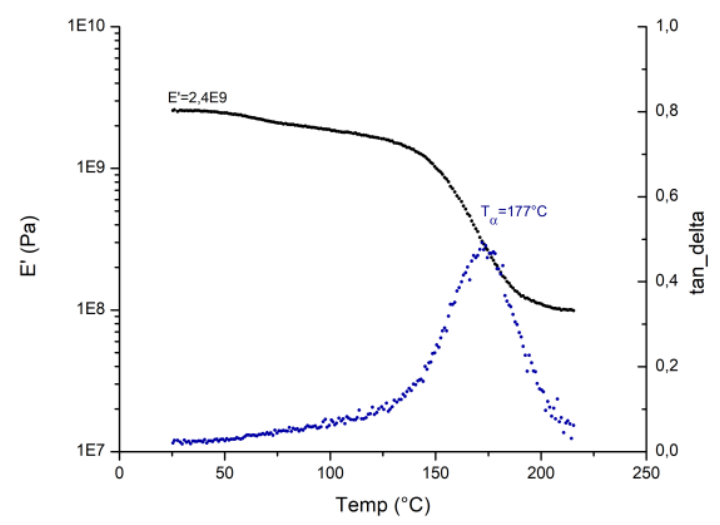

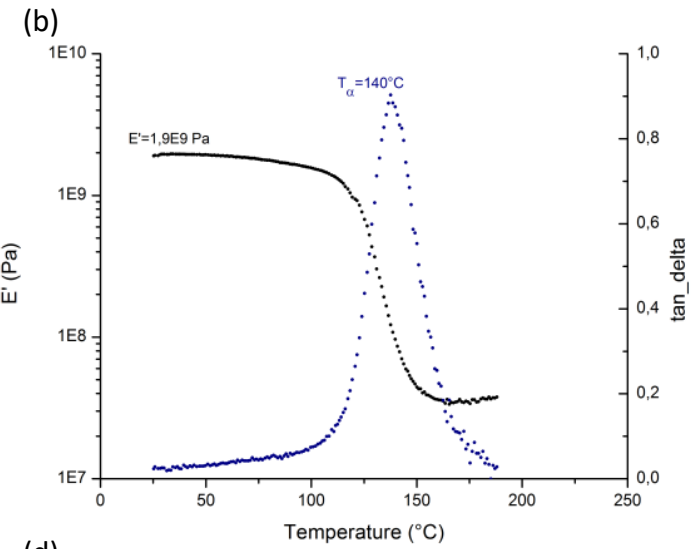

(d)

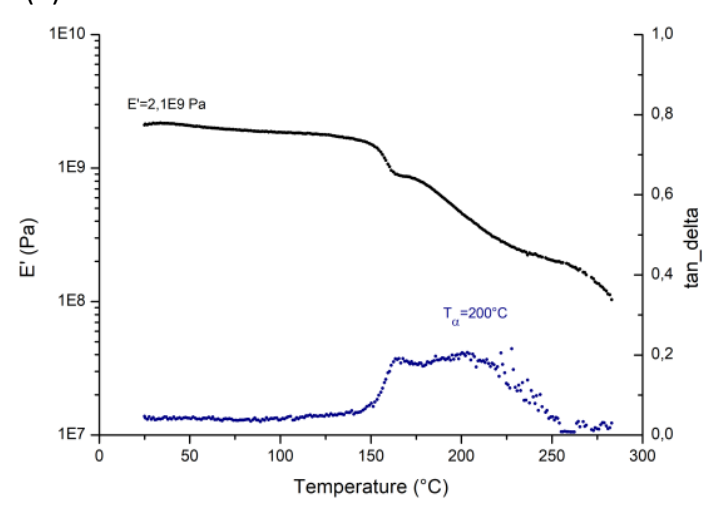

S13 - TGA thermograms of epoxy monomers cured with IPDA under (a) Air (a) and (b) $\mathrm{N}_{2}$

(a)

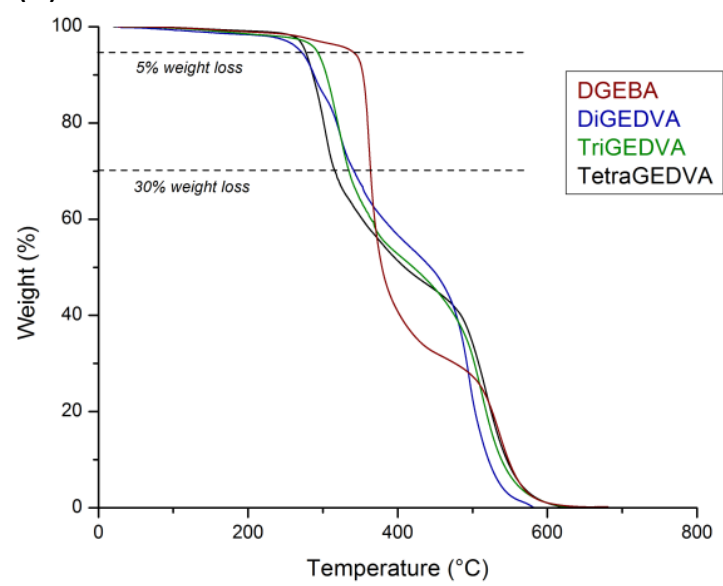

(b)

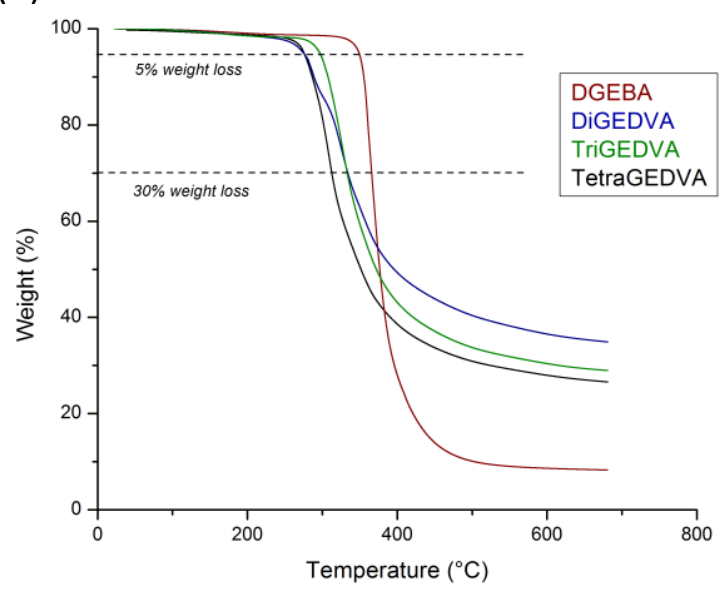


S14 - Tensile test traces of (a)DGEBA, (b) DiGEDVA, (c) TriGEDVA and (d) TetraGEDVA cured with IPDA for $r=1$

(a)

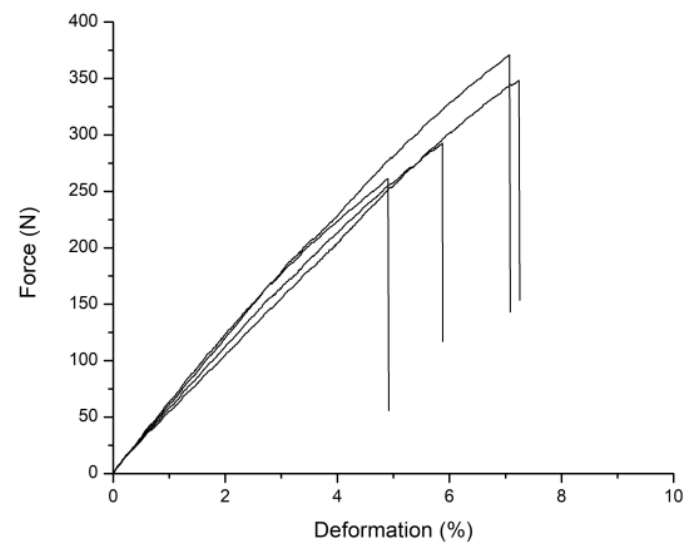

(c)

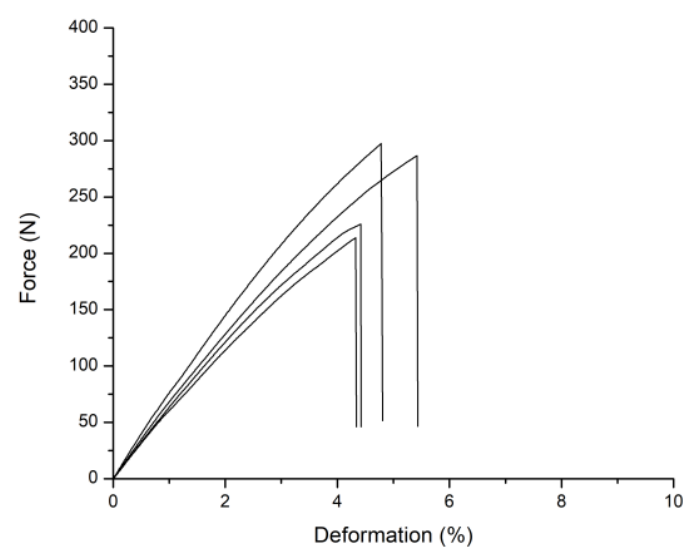

(b)

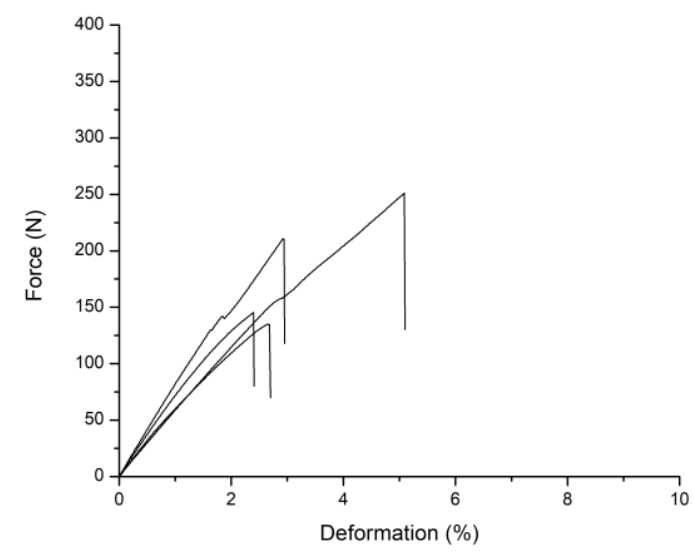

(d)

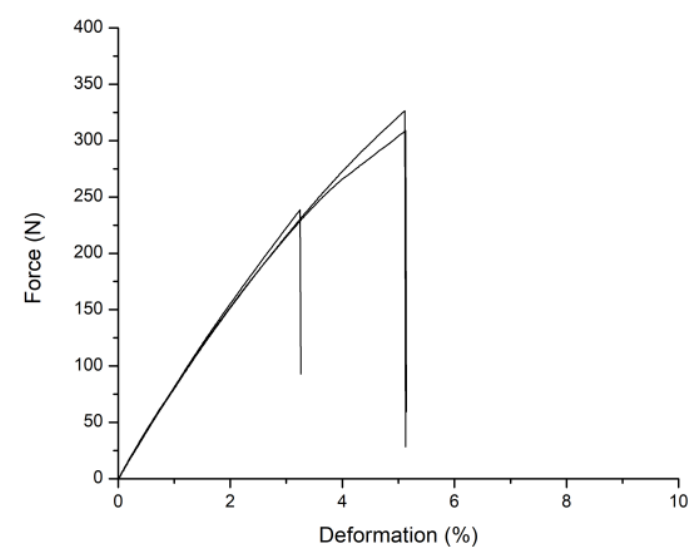




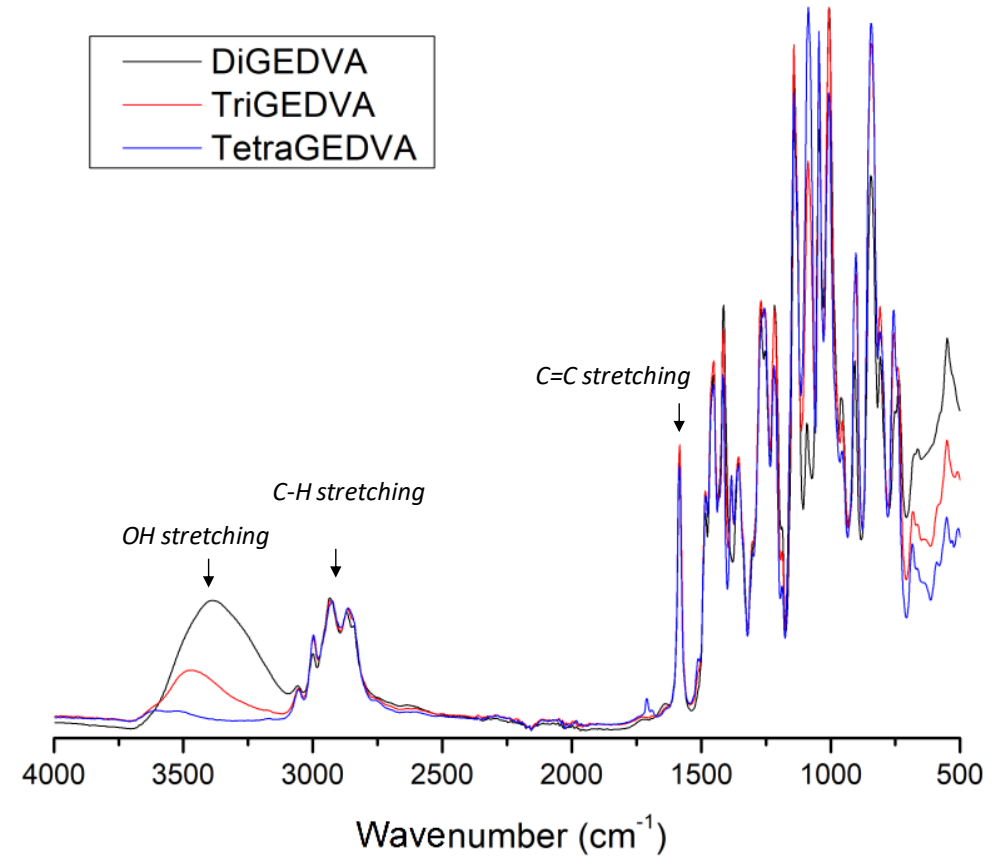

S16 - SEC traces of GEDVA monomers in THF with RI detector and polystyrene calibration
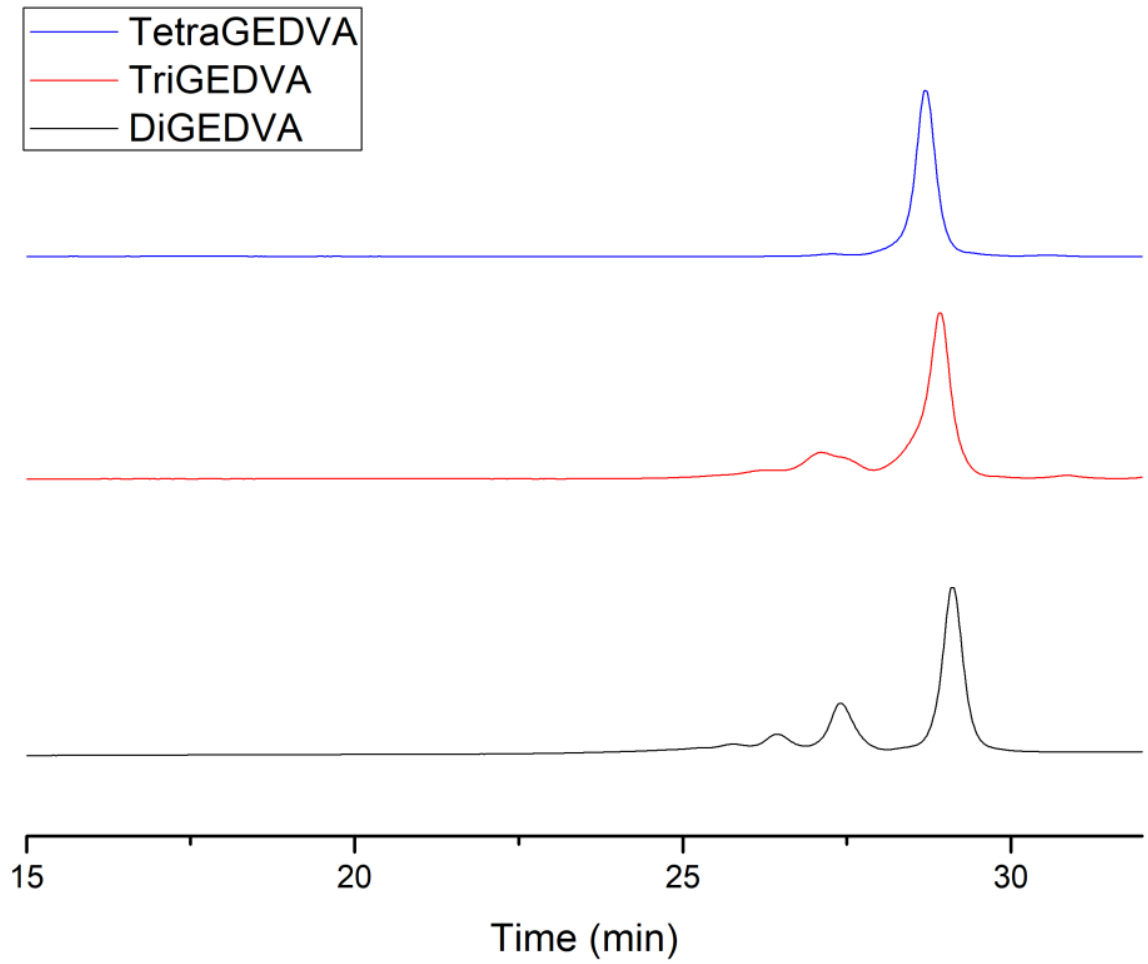
S17 - (a) Glass transition temperature as a function of the epoxy/N-H ratio for DGEBA and TriGEDVA cured with IPDA, (b) DSC thermograms of DGEBA/IPDA for different ratio $r$

(a)

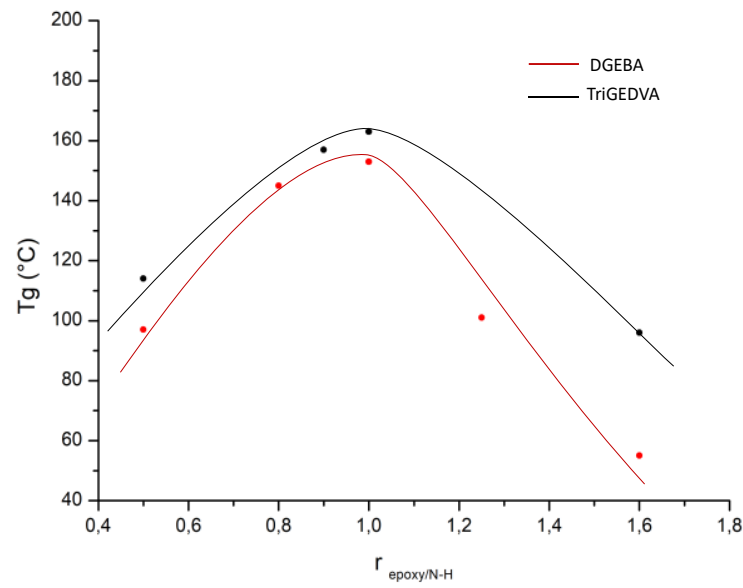

(b)

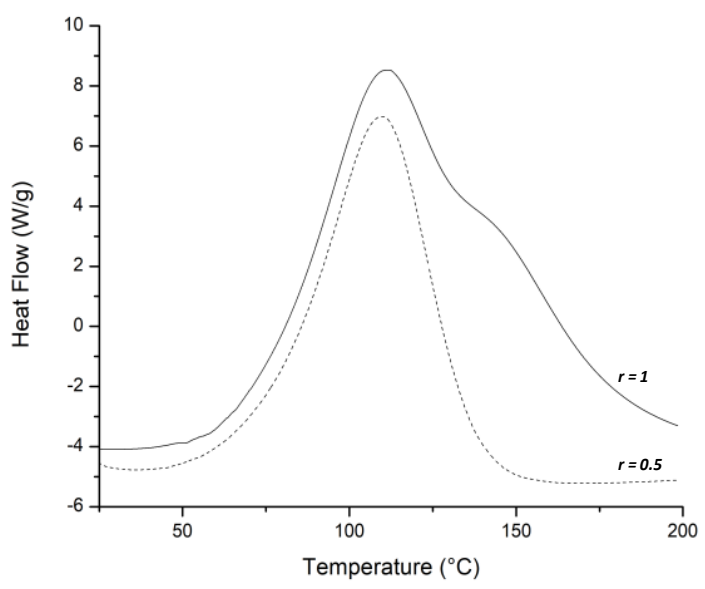

S18 - Thermomechanical properties of epoxy networks cured with IPDA for $r=1$

\begin{tabular}{llllc}
\hline $\begin{array}{l}\text { Epoxy prepolymer } \\
\text { /IPDA }\end{array}$ & $\begin{array}{l}\mathrm{Tg}^{\mathbf{a}} \\
\left.\mathbf{(}^{\circ} \mathbf{C}\right)\end{array}$ & $\begin{array}{l}\mathbf{T}^{\mathbf{b}} \\
\left({ }^{\circ} \mathbf{C}\right)\end{array}$ & $\begin{array}{c}\mathbf{T s}^{\mathbf{c}} \\
\left({ }^{\circ} \mathbf{C}\right)\end{array}$ & $\begin{array}{c}\text { Young's modulus }^{\mathbf{d}} \\
(\mathbf{M P a})\end{array}$ \\
\hline DGEBA & 152 & 155 & 176 & $1337 \pm 102$ \\
Di 60\%-Tri 20\%-Tetra 20\% & 153 & 157 & 155 & $1489 \pm 66$ \\
Di 20\%-Tri 60\%-Tetra 20\% & 166 & 171 & 155 & $1216 \pm 75$ \\
Di 20\%-Tri 20\%-Tetra 60\% & 187 & 197 & 154 & $1545 \pm 110$ \\
\hline
\end{tabular}

${ }^{a}$ determined by $D S C,{ }^{b}$ determined by DMA, ${ }^{c}$ determined by TGA under air, determined by tensile test

S19 - Ternary diagram of (a) Tg determined by DSC, (b) Ta determined by DMA and (c) Young's modulus determined by tensile test for different GEDVA-based monomer blends

(a)

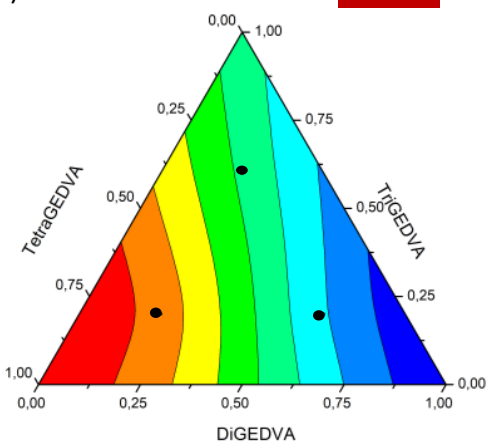

(b)

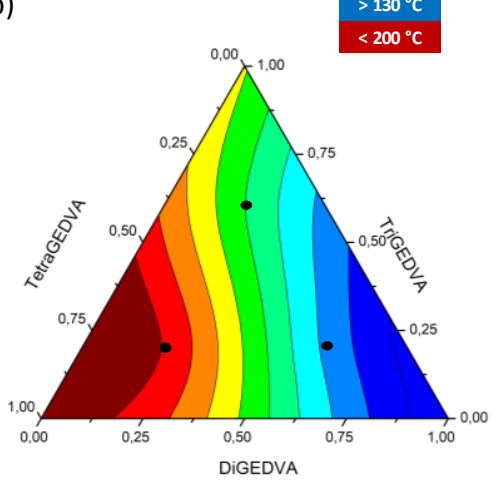

(c)

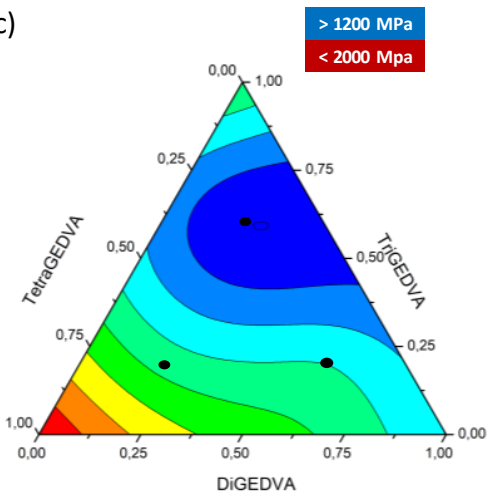

